\title{
THE BROADBAND CREDIBILITY GAP
}

\author{
George S. Ford, $\mathrm{PhD}^{\dagger}$, Lawrence J. Spiwak, Esq. $\ddagger_{\text {and }}$ \\ Michael L. Stern, PhD*
}

\section{INTRODUCTION}

With the D.C. Circuit's recent ruling in Comcast v. FCC,' the court has thrown the Federal Communications Commission's efforts to promote an "Open Internet" into legal limbo. ${ }^{2}$ At the time of this writing, Federal Communications Commission ("FCC") Chairman Julius Genachowski responded by announcing that he would seek to impose a "Third Way" of regulation for broadband. Under the "Third Way" approach, the Commission would reclassify broadband transport as a "telecommunications service" under Title II of the Communications Act, coupled however with aggressive use of the FCC's forbearance authority under Section 10 of the Communications Act to eliminate many of the more burdensome requirements of Title II regulation. ${ }^{3}$ In so

$\dagger$ Chief Economist, Phoenix Center for Advanced Legal \& Economic Public Policy Studies. ₹ President, Phoenix Center for Advanced Legal \& Economic Public Policy Studies. As always, the authors are indebted to Phoenix Center Senior Fellow T. Randolph Beard in helping formulate the various models presented herein. The views expressed in this paper are the authors' alone and do not represent the views of the Phoenix Center, its Adjunct Fellows, or any of its individual Editorial Advisory Board members.

- Senior Fellow, Phoenix Center for Advanced Legal \& Economic Public Policy Studies; Associate Professor of Economics, Auburn University.

1 Comcast Corp. v. FCC, 600 F.3d 642 (D.C. Cir. 2010).

2 In re Preserving the Open Internet, Notice OF PROPOSED Rulemaking, 24 F.C.C.R. 13,064, ๆๆ 2, 10 (Oct. 22, 2009) (hereinafter Open Internet NPRM).

3 Press Release, Federal Communications Commission, The Third Way: A Narrowly Tailored Broadband Framework, Statement of Chairman Julius Genachowski 4-5, available at http://hraunfoss.fcc.gov/edocs_public/attachmatch/DOC-297944A1.pdf (May 6, 2010) [hereinafter Genachowski Statement]. 
doing, the Commission would ostensibly create some sort of "Title II Lite" regulation for broadband Internet services.

An outline for this new regulatory approach to broadband Internet service is provided in statements made by Chairman Genachowski and FCC General Counsel Austin Schlick ("Statements"). ${ }^{5}$ In the Statements, the question of the regulatory classification of broadband services is pitched as a Morton's Fork. ${ }^{6}$ On the one hand, the FCC could retain the Title I classification, but doing so "has a serious risk of failure in court," if the agency attempts to aggressively regulate broadband Internet services. ${ }^{7}$ On the other hand, the FCC could reclassify broadband as a Title II service, but this approach also "has serious drawbacks." Reclassification, the Chairman argues, does "clarify the legal foundation for broadband policy," but reclassification likewise "would also subject the providers of broadband communications services to extensive regulations ill-suited to broadband." "In an effort to resolve this dilemma, the Chairman proposes a "Third Way," where reclassification occurs but the agency "[p]ut[s] in place up-front forbearance and meaningful boundaries to guard against regulatory overreach." 10 The result, allegedly, is a "lite" formulation of Title II regulation, which both Chairman Genachowski and Mr. Schlick suggest has been applied successfully to wireless communications for over a decade."

It is important to keep in mind, as the Statements do, that regulatory classification is not a goal of the regulation but is merely alleged to be a necessary component of the regulatory process. All services subject to regulation must be put into one box or another. ${ }^{12}$ As for goals, Chairman Genachowski claims the

\footnotetext{
4 John Eggerton, FCC to Adopt "Title II Lite" Approach to Web Regulation, BroAD$\begin{array}{llllll}\text { CASTING \& CABLE (May 2010, 4, } & 4: 41 & \text { PM), }\end{array}$ http://www.broadcastingcable.com/article/452298FCC_to_Adopt_Title_II_Lite_Approach_to_Web_Regulation.php.

5 See Genachowski Statement, supra note 3, at 4-5; Press Release, Federal Communications Commission, A Third-Way Legal Framework for Addressing the Comcast Dilemma, Statement of General Counsel Austin Schlick, available at http://hraunfoss.fcc.gov/edocs_public/attachmatch/DOC-297945A1.pdf (May 6, 2010) [hereinafter Schlick Statement].

6 A Morton's Fork is a choice between two equally unattractive alternatives.

7 Genachowski Statement, supra note 3, at 4.

$8 \quad$ Id.

$9 \quad I d$. at 5

10 Id

11 Genachowski Statement, supra note 3, at 6; Schlick Statement, supra note 5, at 5.

12 The Communications Act of 1934, as amended, provides the FCC with express "authority to regulate common carrier services, including landline telephony;" "radio transmissions, including broadcast television, radio and cellular telephony;" and "cable services,"
} 
most basic goal of broadband policy is to "encourage private investment and the building of a communications infrastructure." 13 Likewise, in the National Broadband Plan, the Commission drafted a "plan [describing] actions government should take to encourage more private innovation and investment."14

However, classification, as observed by the Chairman, may have a significant effect on private investment. In his Statement, the Chairman states the dozens of new "[h]eavy-handed prescriptive regulation[s]"15 contained in Title II "can chill investment and innovation" by reducing investors' confidence. ${ }^{16}$ As such, the agency must proceed with caution, as the influence of classification on private investment is a central policy issue.

The Commission's judicial and regulatory dilemma can be summarized by the following question-what is the best regulatory scheme to encourage investment yet provide sufficient authority for only the appropriate regulatory action? By Chairman Genachowski's own logic, Title I ancillary authority is more conducive to investment than Title II classification, since Title I has an exogenously enforced "light touch". Therefore, the Statements must and do argue that the "Third Way" is an effort to make its regulatory choices under Title II much like those under Title I to save investment incentives, but reclassification permits a more solid legal foundation. ${ }^{17}$ That is, reclassification only affects the ease with which the Commission can lightly regulate. Unfortunately, reclassification also affects the ease with which the Commission can heavily regulate if it chooses to do so. Under the existing ancillary approach to regulation, the burden is on the agency to make a compelling and legally sound case for regulatory intervention in the broadband marketplace. The upshot of this approach is an embedded judicial discipline on intervention, thereby sig-

including cable television." Comcast Corp., 600 F.3d at 645. See also James B. Speta, The Shaky Foundations of the Regulated Internet, 8 J. ON TELECOMM. \& HIGH TECH. L. 101, 106 (2010).

13 Genachowski Statement, supra note 3, at 1. Notwithstanding the Chairman's comment, we stress that increasing investment and jobs are not legitimate policy goals. Public policy should aim to increase social surplus (consumer plus producer surplus) in an economically efficient manner. For example, say there are two technologies that can generate the same social surplus, but one requires more labor and capital than the other. Obviously, the economically-sound decision is to the use the technology that requires fewer inputs of production, even though it means lower capital expenditures and fewer jobs.

14 FED. COMMC'NS COMM'N, CONNECTING AMERICA: The NATIONAL BroadBand Plan 5 (2010) available at http://download.broadband.gov/plan/national-broadband-plan.pdf [hereinafter NATIONAL BROADBAND PLAN].

15 Genachowski Statement, supra note 3, at 2.

$16 I d$. at 2.

17 See Schlick, supra note 5, at 4-5; Genachowski, supra note 3, at 5. 
naling to investors there is a "light touch" regulatory approach to broadband services, and this relaxed regulation is enforced exogenously (i.e., by the courts). The "Third Way" or reclassification approach, in contrast, opens the door to heavy-handed regulation, thereby requiring the Commission to exercise substantial self-imposed discipline to limit regulatory intrusion. If not, investment is "chilled." From a legal standpoint, therefore, the Commission can either (a) rely on the courts to impose discipline on its regulation of broadband; or (b) rely on its own self-control, now and in the future, to enforce regulatory restraint in a world where it will have both the authority, and the political motivation, to intervene. As shown below, the second approach lacks credibility with the capital markets. Consequently, the Title I approach leads to more private investment.

Without debate, reclassification greases the wheels of the regulatory machine for both light-and heavy-handed regulations. As such, the argument over reclassification is thus reduced to one of credibility - can the Commission be trusted to self-impose regulatory moderation, thereby maintaining efficient investment incentives? ${ }^{18}$ In light of its past and current actions, as will be discussed below, the answer is almost surely "no." Even if the Commission today has such discipline, and we demonstrate it does not, the adverse effect on capital markets and industry investment remains intact because it is the beliefs of the participants in the financial markets that matter in this regard, not those of the Commission. As we show below (in Section III.B. 2), evidence from the financial markets indicates that the agency lacks credibility for light touch regulation and, consequently, a contraction in investment is expected in response to reclassification (ceteris paribus).

To explore this important topic, this article is organized as follows. First, we analyze the reclassification issue in terms of a "broadband credibility gap." We provide a simple game theoretic analysis that exposes the underlying issue surrounding regulatory classification and credibility. In so doing, we demonstrate that a "light touch" toward regulating broadband is not credible (it is not a subgame equilibrium). Moreover, we use the current Commission's own actions to demonstrate it lacks the necessary self-discipline or mindset for light touch

18 As explained in more detail in Section II.A below, "credibility" does not mean, and should not be identified with, "honesty." Rather, when we argue that the Commission's claim that it will forbear from heavy-handed exercise of its regulatory authority, we mean only that this claim will not be found convincing ex ante by either the firms being regulated, nor, more importantly, the capital markets on which these firms must usually rely for financing of their investment projects. This is so because the promise will not be in the interest of the Commission to actually carry out, should circumstances unfold in a particular manner. 
regulation. Second, we consider the investment effects of reclassification using a theoretical model of investment. In this model, a firm faces either "weak" or "strong" regulation. This model shows that an increase in the ex ante probability of "strong" regulation-that is, reclassification-weakens investment incentives. This result is largely non-controversial and is consistent with the claim of Chairman Genachowski that heavy-handed regulation chills investment, and the response of the financial markets further indicates a decline in investment incentives from reclassification. Whether or not reclassification results in heavy-handed regulation has yet to be determined, but the regulatory change certainly increases the probability of heavy-handed regulation. As such, the causal connection between reclassification and reduced investment is in force, irrespective of actual agency action. Third, we provide evidence from the financial markets supporting the negative investment effects implied by the theory. This same evidence also reveals that investors have no confidence that the Commission possesses the self-discipline required to successfully implement "light touch" regulation. Next, we argue that the Comcast decision is not a threat to ancillary authority for broadband, and that if the Commission keeps its focus on preventing demonstrated cases of harm (as opposed to repeating its efforts to impose broader price regulation on broadband service providers), Title I continues to provide a sound legal footing to protect consumers from harm-at least until Congress decides to update and amend existing Communications law. Further, Title I classification contains an exogenously enforced barrier to more aggressive regulation-that is, the courts. By Chairman Genachowski's own argument, such exogenous barriers to "overreaching" are desirable for the maintenance and expansion of private investment. Concluding comments close the report.

\section{THE "BROADBAND CREDIBILITY GAP"}

The Statements by FCC officials purport to describe a "Third Way" for regulating broadband Internet services. This "Third Way" is supposed to be necessary given dissatisfaction with the two other ways that the agency could proceed. As detailed in the Statements, the "first option" is to "continu[e] to pursue policies with respect to broadband Internet access under the ancillary authority approach." 19 Given the Comcast decision, the Chairman opines that this option "has a serious risk of failure in court," 20 though, as argued below, 
his interpretation of Comcast is debatable. Much of the Commission's regulation occurs under ancillary authority, ${ }^{21}$ and the courts have repeatedly affirmed the presence and enforceability of the Commission's ancillary authority. ${ }^{22}$ In fact, the courts have been fairly deferential on ancillary authority when the Commission makes sound arguments. ${ }^{23}$

The second option is "reclassifying broadband services as "telecommunications services' and applying the full suite of Title II obligations." 24 According to the Chairman, this approach is likewise problematic, in that it imposes "extensive regulations ill-suited to broadband," it "fail[s] to reflect the longstanding bipartisan consensus that the Internet should remain unregulated," 25 and it can "chill investment and innovation." 26

The alleged shortcomings of these two options-a "serious risk of failure in court" with respect to Title I and "extensive regulation [that will] chill investment" with respect to Title II-leads the Chairman to propose the "Third Way." ${ }^{27}$ In this approach, broadband is first reclassified as a telecommunications service, thereby providing the Commission the authority to apply "the full suite of Title II obligations"28 including "[h]eavy-handed prescriptive regulation." 29 On its own initiative, however, the Commission would then promise to "[a]pply only a handful" of such regulations, putting "in place up-front forbearance and meaningful boundaries to guard against regulatory overreach." This "but for" approach to reclassification acquires a "sound[] legal founda-

21 For nearly 70 years, the Supreme Court has recognized the FCC's ancillary authority. Since then, the FCC has relied on this authority to regulate "communications matters not directly addressed elsewhere in [the FCCC's statutory authority]." This authority has been used to regulate broadcast television, cable television, and Internet service. See generally Brief for Respondents at 41-45 Comcast Corp. v. Fed. Commc'ns Comm'n, 600 F.3d 642 (D.C. Cir. 2009) (No. 08-1291), 2009 WL 3557928 [hereinafter "FCC Brief"].

22 See, e.g., FCC Brief, supra note 21, at 34-35. See infra Part IV.A (discussing reasons why the FCC lost in Comcast). For nearly 70 years, the Supreme Court has recognized the FCC's ancillary authority. Since then, the FCC has relied on this authority to regulate "communications matters not directly addressed elsewhere in [the FCC's statutory authority]." Id. This authority has been used to regulate broadcast television, cable television, and Internet service.

23 See FCC v. Nat. Citizens Comm. For Broad., 436 U.S. 775, 796 (holding that regulations were valid because they were within reasonable means to achieving a public interest goal).

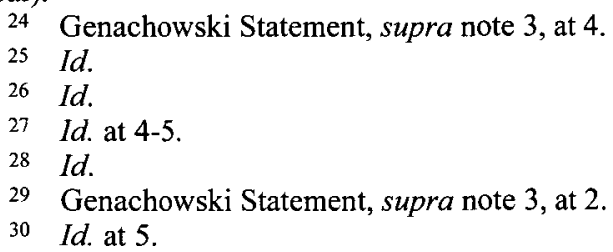


tion" 31 in return for exposing broadband Internet services to "dozens of new regulatory requirements" 32 of the "extensive" and "heavy handed prescriptive" sort. ${ }^{34}$ "But for" a promise of self-imposed regulatory discipline now and in the future by a regulatory institution-the Federal Communications Commission-a reduction to investment would follow. ${ }^{35}$ Indeed, the Chairman recognizes that if these boundaries "unravel," then investor confidence will wane. ${ }^{36}$ In other words, if the Commission fails to exercise self discipline, the chilling effect of reclassification is, by the Chairman's own logic, in full effect.

Both Chairman Genachowski and Mr. Schlick repeatedly point to the requirement of "meaningful boundaries" and "up-front forbearance" so that the "renunciation of regulatory overreach will not unravel," yet it is clear to both that this Third Way cannot, in their own words, "prevent the Commission from adjusting its future policies in light of changed circumstances." ${ }^{37}$ Commissioner Clyburn agrees, stating that "there is no such thing as certainty" in the regulatory context. ${ }^{38}$ Therefore, the Commission cannot really pre-commit to "light touch" regulation after its proposed reclassification. As revealed by game theory, this lack of pre-commitment presents serious problems for the Third Way. We describe such problems briefly and then explore the various arguments to support the Third Way in more detail below.

\section{A. Pre-Commitment and Credibility: A Game Theoretic Analysis}

In this paper, we view reclassification in terms of a "broadband credibility gap." The idea of credibility has a very specific meaning in game theory. Although in some respects this is a common sense notion, the game-theoretic treatment has a fundamental advantage over the ordinary application of this term. Specifically, "credibility" does not mean, and should not be identified with "honesty." Rather, when we argue that the Commission is not credible

\footnotetext{
31 Id. at 5 . The Chairman argues that Title II reclassification would chill investment "but for" the heavy use of forbearance.

2 Id. at 4.

Id.

Genachowski Statement, supra note 3, at 2.

Id.

Id. at 5 .

Id. at 5; Schlick Statement, supra note 5, at 4, 8-9.

38 Mignon L. Clyburn, Commn'r, Fed. Commc'ns Comm'n, Prepared Remarks before the Media Institute, (June 3, 2010) (available at http://hraunfoss.fcc.gov/edocs_public/attachmatch/DOC-298599A1.pdf) (hereinafter Clyburn June 3, 2010 Speech).
} 
when it claims that it will forbear from heavy-handed exercise of its regulatory authority, we mean only that this claim will not be found convincing ex ante by neither the firms being regulated nor, more importantly, the capital markets upon which these firms must usually rely for financing of their investment projects. This is so because the promise will not be in the interest of the Commission to actually carry out, should circumstances unfold in a particular manner. The Commission's actions need not necessarily be motivated by a bad intent, but can conservatively be assumed to maximize surplus in future periods after the investment is sunk. Thus, the problem need not be one of the Commission acting in a manner contrary to the public welfare in the future (though we cannot exclude the possibility it will), but the agency's future decisions are made after investments are made (i.e. sunk). A very simple extensive form game from most game theory textbooks illustrates this important, yet subtle, point. ${ }^{39}$

Suppose two players, A and R, will play the following simple game illustrated in Figure 1. First, player A will make a choice between two irreversible options, which we designate I (invest) or 0 (do not invest). For simplicity of presentation, suppose this decision is observed by $\mathrm{R}$ (the regulator). Player $\mathrm{R}$ then makes a choice between actions $\mathrm{H}$ (strong or heavy regulation, say) or $\mathrm{L}$ (light regulation). Having made this choice, the game ends and the players $A$ and $R$ receive the payoffs given below, depending on the sequence of choices made by the participants (with A's payoff given first).

Figure 1. The Extensive Form Game

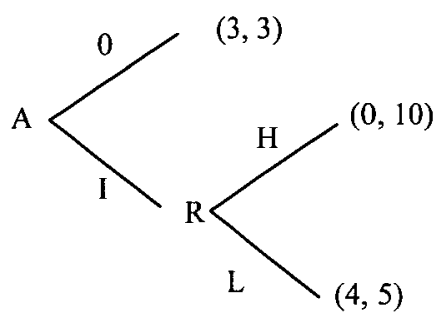

Several points about this simple example deserve comment. First, A must make her investment decision by forming an expectation regarding the prob-

39 See, e.g., Ken Binmore, Game Theory: A Very Short InTROduction (Oxford Univ. Press 2007). 
able response of $R$. Because we assume $A$ and $R$ are interested in maximizing their own payoffs, A would only be willing to make the choice I (make the sunk investment) if $\mathrm{A}$ expected $\mathrm{R}$ to respond by implementing the choice $\mathrm{L}$ (light regulation). This is so because $A$ can assure herself of a profit of 3 by selecting the choice 0 . Clearly, though, $R$ 's probable response to the choice $I$ is not a mystery here: $\mathrm{R}$ will maximize his payoffs by selecting $\mathrm{H}$ (heavy regulation) and obtaining the payoff 10 instead of 5. Thus, A rationally expects the choice $I$ to be followed by the choice $H$ by player R. Consequently, A's investment decision problem is solved: A will do best by selecting 0 at the beginning, and obtaining the payoff of 3 .

We call attention to two more features of this simple example. First, if player $R$ could credibly promise to select the choice $L$ in the event that A chose I, then A would willingly do so, and the payoffs $(4,5)$ would be obtained, and both $A$ and $R$ would be better off than they are when $A$ chooses 0 . In particular, $\mathrm{R}$ would surely wish to be able to convince $\mathrm{A}$ that such would be the case. Unfortunately, given the payoffs written here, that is a difficult task because A will realize that $\mathrm{R}$ has no actual incentive to select $\mathrm{L}$ should the opportunity actually arise.

Second, if one regards the sums of the players' payoffs as representative of society's levels of aggregate welfare or benefit for the different combinations of actions, then we see that the outcomes can be ranked, from most to least socially desirable, in the order $(I, H),(I, L)$, and finally $(0$, any choice). This rank has several implications. $R$ 's choice of $H$ in response to A's selection of I is, in fact, socially desirable, and $\mathrm{R}$ cannot be criticized for selecting $\mathrm{H}$ from the social point-of-view. However, the actual outcome ("equilibrium") of this game has A selecting 0 , which makes both the firm and the regulator ( $A$ and $R$ ) worse off than the choices (, $\mathrm{L}$ ). Thus, the inability of Player R to credibly promise to respond with action $\mathrm{L}$ is costly to everyone. Chairman Genachowski, Austin Schlick, and Commissioner Clyburn have all agreed that no such commitment is possible, ${ }^{40}$ thereby leading to the broadband credibility gap. Commissioner Copps has expressed outright his distaste for "light touch" Title II regulation. ${ }^{4 !}$

40 Genachowski Statement, supra note 3, at 5; see Schlick Statement, supra note 5, at 8 (stating that "[A]lthough neither approach would, could, or should absolutely prevent the Commission from adjusting its future policies in light of changed circumstances, "). See Clyburn June 3, 2010 Speech, supra note 38, at 3 (stating that "there is no such thing as certainty" in the regulatory context).

41 See Press Release, Fed. Commc'ns Comm'n, Statement of Commissioner Michael J. Copps on Chairman Genachowski's Announcement to Reclassify Broadband (May 6, 2010),

(Footnote Continued....) 
How, then, might the inefficiency illustrated by this game be avoided? There appear to be two immediate solutions. First, if R could compel A to select I, the payoffs $(0,10)$ could be obtained, and these are socially best. If, however, no such mechanism exists, one could consider the alternative approach in which B somehow eliminates its choice $\mathrm{H}$. This option has a large advantage over the first, as it is sometimes possible for players to credibly limit their own options by making a binding agreement with a third party, while it is often infeasible for one player to effectively command the actions of another. This is the essential defect in the Third Way-the Statements attempt an argument for commitment (e.g., "meaningful boundaries to guard against regulatory overreach") ${ }^{42}$ but, in the end, recognize such a commitment is impossible (i.e., "prevent the Commission from adjusting its future policies in light of changed circumstances"). ${ }^{43}$ The Third Way lacks credibility and, consequently, the negative effects of heavy-handed regulation are expected to ensue.

To summarize, this example illustrates a basic problem with regulation when the regulator is unable to credibly convince private investors of its future regulatory behavior. Firms and investors make decisions based on their profitability, and this profitability depends on how they will be regulated going forward. ${ }^{44}$ Society may well benefit, in aggregate, if these investments are made. Yet the prospect of heavy regulation reduces profits and can dissuade investors from the outset. This result does not depend on erratic behavior by the regulator: on the contrary, the regulator may well act with the welfare of society foremost in its mind. Unless the regulator is able to take steps to assure investors it will behave favorably, though, society may suffer. Such assurances from regulators, by their own admission, are ephemeral in nature. A benefit of Title I classification is that the "light touch" is enforced exogenously by the courts, forcing the Commission to present compelling and well-crafted arguments for regulatory intervention.

available at $\mathrm{http}: / / \mathrm{hraunfoss} . \mathrm{fcc} . g o v / \mathrm{edocs}$ public/attachmatch/DOC-297946A1.pdf) [hereinafter Copps Statement]("Frankly, I would have preferred plain and simple Title II reclassification").

42 Genachowski statement, supra note 3, at 5.

43 Schlick Statement, supra note 5, at 8.

44 See, e.g., THOMAS W. HAZLETT, AEI-BRookING JoINT CTr. For REgULATORY STUdIES CONVERGENCE BROADBAND COMMUNICATIONS, REgulation aNd VERTICAL INTEGRATION BROADBAND ACCESS AND SUPPLY 5, 11 (Feb. 15, 2002) (noting that telephone companies are more heavily regulated than cable television companies and, as a result, cable companies have been more aggressive in the high-speed Internet marketplace); see also id. at 12 (stating that the threat of regulation "for cable operators has negatively impacted investment incentives"). 


\section{B. Credibility in Light of Action}

Chairman Genachowski essentially sets forth five arguments as to why the Commission can be trusted not to capitulate to temptation and aggressively apply its new and improved regulatory authority. They are, in no particular order, that: (1) the FCC will not seek to impose price regulation; (2) "Title II Lite" is just like the paradigm set forth by Congress in Section 332 for commercial mobile radio services ("CMRS") or wireless services; (3) forbearance will be a relatively easy and innocuous process; (4) the Commission is unlikely to reverse any forbearance decision; and (5) local loop unbundling is not on the table. We evaluate each in turn, and find that the Commission's actions under Chairman Genachowski belie each and every argument. ${ }^{45}$

\section{This Commission has Already Tried to Impose Price Regulation}

Mr. Genachowski argues that the "Title II Lite" paradigm would "not change established policy undertakings at the FCC . . . such as the practice of broadband prices or pricing structures." ${ }^{146}$ Unfortunately, this statement appears to be inconsistent with the Commission's actions under his tenure as Chairman.

First, the Commission's initial proposal to regulate the Internet-last autumn's "Open Internet" Notice of Proposed Rulemaking-is unambiguously price regulation of Internet carriers. ${ }^{47}$ Under the plain terms of the FCC's proposal contained in this Notice, the "non-discrimination" rule mandates "that a broadband Internet access service provider may not charge . . for enhanced or prioritized access . . . "48 Any rule that mandates that a firm "may not charge" is unquestionably price regulation. Consequently, one of Chairman Genachowski's first proposals was to price regulate broadband services. Furthermore, the requirement to sell two completely different services at the exact same price has nothing to do with preventing discrimination. ${ }^{49}$ Put simply, the

45 See discussion infra Parts II.B.1-5.

46 Genachowski Statement, supra note 3, at 5.

47 GeORge S. Ford \& LAWRENCE J. SPIWAK, PHOENIX CTR. FOR THE AdVANCED Legal \& ECON. PUB. POL'Y. STUdies, NON-DisCRIMINATION OR JUST NON-SENSE: A LAW AND EConomics Review of the FCC's New Net Neutrality Principle 5 (March 24, 2010), available at http://www.phoenix-center.org/perspectives/Perspectivel0-03Final.pdf.

48 Open Internet NPRM, supra note 2, at $\uparrow 106$.

49 See ForD \& SPIWAK, supra note 47, at 4. Authors note that the FCC's attempt to craft a new bright line non-discrimination rule is "plainly incompatible" with accepted notions of non-discrimination. Id. at 1-2. In its Open Internet NPRM, the FCC fails to realize that discrimination requires services to be identical-'labeling as 'discrimination' different prices for 
non-discrimination rule is not about discrimination, it is about price regulation.

And, even worse, the Commission's proposed price regulation rules in the Open Internet NPRM are completely incompatible with the very statutory mandate Mr. Genachowski now wants to re-impose on broadband service providers in the form of Sections 201 and 202. Traditional Title II jurisprudence rejects the Commission's presumed "bright line" non-discrimination standard in favor of the more nuanced concept of "undue" discrimination. Title II allows carriers to sell different services at different prices, so long as all of the offerings are available to similarly situated customers. ${ }^{50}$ If the Open Internet NPRM is adopted as currently drafted, however, carriers would be forced to sell two completely different services (enhanced and standard service) for the same price in evident violation of Section 202. ${ }^{51}$

Second, the Commission currently has (at least) two proceedings open to expand regulatory oversight-including pricing regulation-of broadband transport. In the National Broadband Plan Public Notice \#11, the Commission requested information on the pricing, costs, and degree of competition in high capacity broadband transport markets in an effort to address claims that a lack of "adequate, reasonably priced, and efficiently provided access to middle and second mile transport services and facilities play an important - if not gatingrole in the economics of broadband deployment." ${ }^{52}$ In the Special Access $N P R M$, the Commission is specifically considering the expansion of price regulation over high capacity broadband data links, again contemplating a reversal of earlier Commission actions, by (re)imposing price regulations on broadband services. $^{53}$

different goods is a fundamental defect in the Commission's approach." Id. at 3-4.

so See Orloff v. FCC, 352 F.3d 415, 420-421 (D.C. Cir. 2003) (holding that commercial mobile radio service (CMRS) provider's practice of granting sales concessions to some prospective customers was a reasonable response to competitive market conditions and was not "unjust or unreasonable" rate discrimination against other similarly-situated customers in violation of the Communications Act). See, e.g., MCI Telecommunications Corp. v. FCC, 917 F.2d 30, 39 (D.C. Cir. 1990).

51 See FORD \& SPIWAK, supra note 47, at 5-6. Moreover, it is important to note that, in the Open Internet NPRM, the Commission tries to price regulate not under Sections 201 and 202, but under a tortured interpretation of Section 251. Id. at 4. However, such an approach is wholly inconsistent with the Commission's original interpretation of Section 251 in 1996, which clearly permitted pricing differentials for different services. See generally id.

52 Comment Sought on Impact of Middle and Second Mile Access on Broadband Availability and Deployment, NBP Public Notice \#11, Public Notice, 24 F.C.C.R. 12,470 (Oct. 8, 2009). The services at issue are "transport and transmission of data communications." Id.

53 See In re Special Access Rates for Price Cap Local Exchange Carriers, AT\&T Corp. Petition for Rulemaking to Reform Regulation of Incumbent local Exchange Carrier Rates for Interstate Special Access Services, Order and Notice of Proposed Rulemaking, 20 
While we make no particular claims here about the wisdom of these two current investigations, we believe that these examples-coupled with the Commission's blatant actions in the Open Internet NPRM to impose price regulation on Broadband Service Providers ${ }^{54}$ - presents strong evidence that this Commission views price controls as a legitimate policy lever. The revisiting and reversal of previous decisions is precisely the kind of temporally inconsistent behavior that plagues the FCC's proposal.

But there is also other, less direct evidence that price regulation is on the table. For example, in a recent FCC consumer survey conducted as part of the National Broadband Plan, the FCC staff established a price point of $\$ 25$ per month as what people consider to be "affordable."ss The mission of the $\mathrm{Na}$ tional Broadband Plan is "affordable broadband," and the Plan claims that the largest barrier to adoption is price. ${ }^{56}$ Application of Section 201, as proposed by the Commission, requires rates to be "affordable" (notwithstanding the fact that the Act clearly contains no such arbitrary subjective standard, but rather a fact-based inquiry into whether rates are "just and reasonable" ${ }^{37}$ ). Thus, the FCC's plain interest in price regulation of broadband services has been established; a price exceeding $\$ 25$ is "unaffordable". 58 Similarly, the National Broadband Plan stated that the FCC intends to conduct a more granular market-by-market analysis of the state of competition, including gathering and analyzing price data. ${ }^{59}$ The National Broadband Plan proposes to "[c]ollect,

F.C.C.R. 1994, 2012-13, I 51 (Jan. 31, 2005). See also GEORGE S. Ford \& LAWrenCE J. Spiwak, Phoenix Ctr., Phoenix CTr. Pol'y PAPer No. 35: The Need for Better AnalySIS OF HIGH CAPACITY SERvICES 2-3 (Jun. 2009), available at http://www.phoenixcenter.org/pcpp/PCPP35Final.pdf; T. Randolph Beard et al., Phoenix Ctr., Phoenix CTR. POL'y PAPER No. 37: MARKET Definition AND THE ECONOMIC EFFECTS OF SPECIAL ACCESS REGULATION 2-3 (Oct. 2009), available at http:/www.phoenixcenter.org/pcpp/PCPP37Final.pdf.

54 See supra Part II.B.1 and accompanying notes 45-54; see generally FORD \& SPIWAK supra note 47 (discussing the FCC's proposal to implement regulations for the purpose of preserving Open Internet).

55 John B. Horrigan, Broadband Adoption and Use in America 28 (Fed. Commc'ns Comm'n, OBI Working Paper Series No. 1, Feb. 2010), available at http://hraunfoss.fcc.gov/edocs_public/attachmatch/DOC-296442A1.pdf.

56 NATIONAL BROADBAND PLAN, supra note 14, at 9, 167-168.

57 See Farmers Union Central Exchange v. FERC, 734 F.2d 1486, 1503-1505 (D.C. Cir. 1984) (the phrase "just and reasonable" is not "a mere vessel into which meaning must be poured").

58 See Horrigan, supra note 55, at 28.

59 National Broadband Plan, supra note 14, at 29 (stating that "continuous collection and analysis of detailed data on competitive behavior must be the linchpin of effective competition policy"). 
analyze, benchmark and publish detailed, market-by-market information on broadband pricing and competition... This will also enable the FCC and other agencies to apply appropriate remedies when competition is lacking in specific geographies or market segments." ${ }^{\text {" }}$ Although not definitive statements of intent, the National Broadband Plan can easily be interpreted as opening the door to price regulation as an appropriate remedy for prices that are deemed unaffordable. More evidence that the Commission leans toward price regulation is discussed in the next section, citing several examples of investigations and proceedings underway at the agency.

\section{This Commission has Already Attempted to Regulate the Wireless Industry}

Although the FCC has classified wireless broadband as a Title I information service since 2007, ${ }^{61}$ Chairman Genachowski maintains that his proposed Third Way approach has been successfully applied to traditional wireless communications. ${ }^{62}$ However, while it is indeed true that Congress gave the Commission specific forbearance authority over the pricing provisions in Title II pursuant to Section 332(c) of the Communications Act, ${ }^{63}$ CMRS services remains subject to a plethora of regulations under both Title II and Title III. ${ }^{64}$ As such, it is somewhat odd that the agency would appeal to their treatment of the wireless industry to support its "light" touch.

More importantly, it does not appear that this Commission anticipates easing the imposition of wireless regulations any time soon and is, in fact, considering expanded regulation for such services in numerous proceedings. For example, not only is the Commission currently contemplating subjecting wireless broadband providers to the pricing rules contained in the Open Internet $N P R M,{ }^{65}$ but it is also still considering the potential application of mandatory "Wireless Carterfone" rules, ${ }^{66}$ which could lead to higher handset prices ${ }^{67}$ and perversely

\section{Id. at XI (emphasis added).}

61 In re Appropriate Regulatory Treatment for Broadband Access to the Internet Over Wireless Networks, Declaratory Ruling, 22 F.C.C.R. 5901, 5908-11, ๆ1 18-28 (Mar. 23, 2007); In re Appropriate Regulatory Treatment for Broadband Access to the Internet Over Wireless Networks, Concurring Statement of Comm'r Michael J. Copps, 22 F.C.C.R. 5927 (Mar. 23, 2007).

62 Genachowski Statement, supra note 3, at 6.

63 Schlick Statement, supra note 5, at 5; 47 U.S.C. $\$ 332$ (c) (2006).

64 Schlick Statement, supra note 5, at 5 (explaining that the FCC may not forbear from enforcing sections 201, 202, and 208 under Title II and that the FCC has "direct jurisdiction over licensing of wireless services under Title III).

65 Open Internet NPRM, supra note 2, 11 171-174.

66 See Id. I 25 (Carterfone rules required "phone compan[ies] to allow subscribers to 
create the incentive for wireless BSPs to engage in exclusionary conduct such as sabotage. ${ }^{68}$ Moreover, last winter, the Commission requested information about early termination fees ("ETFs"), asking the carriers to "describe the rationale for the increase in the ETF." ${ }^{69}$ The ETF is an element of the price vector, and such inquisitions may be sensibly viewed as a prelude to price regulation. Indeed, in the Commission's recent Wireless Competition Report, the Commission described ETFs as "probably the largest quantifiable cost to consumers who wish to switch service providers."70 Most recently, there is the Commission's much heralded "Bill Shock" proceeding, which one can only read as being expressly designed to challenge the current paradigm of no price regulation and handset subsidies. ${ }^{71}$

attach their choice of devices to the network," leading to considerable innovation in phone technology). See id. If 163-170 (requesting comments regarding regulations that would require broadband service providers to allow subscribers to use any device to access their networks).

67 George S. Ford, et al., Phoenix Ctr. for the Advanced Legal \& Econ. Pub. Pol'y. Studies Pol'y PaPer No. 21, Consumers and Wireless Carterfone: AN ECONOMIC PERSPECTIVE 9 (Sept. 2008), available at http://www.phoenixcenter.org/policybulletin/pcpb17final.pdf.

68 George S. Ford, et al., Phoenix Ctr. For the Advanced Legal \& Econ. Pub. Pol'y. StUdies Pol'y PAPER No. 17, Wireless NeT NeUTRality: From Carterfone T CABLE BOXES 5 (APR. 2007) available at http://www.phoenixcenter.org/policybulletin/PCPB17Final.pdf.

69 Letter from Ruth Milkman, Chief, Wireless Telecomm. Bureau, Fed. Commc'ns Comm'n [hereinafter Ruth Milkman], and Marc Stone, Acting Chief, Consumer and Gov't'l Affairs Bureau, Fed. Commc'ns Comm'n, to Steven E. Zipperstein, Vice President of Legal and External Affairs, General Counsel and Sec'y, Verizon Wireless (Dec. 4, 2009), 24 F.C.C.R. 14320, 14321, DA 09-2535. See e.g., letter from Joel Gurin, Chief of Consumer and Gov't'l. Affairs Bureau, Fed. Commc'ns Comm'n [hereinafter Joel Gurin] and Ruth Milkman, to Robert Quinn, Senior Vice President - Federal Regulatory, AT\&T Services, Inc. (Jan. 26, 2010), 25 F.C.C.R. 918, DA 10-132; letter from Joel Gurin and Ruth Milkman, to Richard S. Whitt, Washington Telecom and Media Counsel, Google Inc. (Jan. 26, 2010), 25 F.C.C.R. 922, DA 10-133; letter from Joel Gurin and Ruth Milkman to Thomas J. Sugrue, Vice President, Gov't Affairs, T-Mobile USA, Inc. (Jan. 26, 2010), 25 F.C.C.R. 933, DA 10-135; letter from Joel Gurin and Ruth Milkman to Kathleen Grillo, Senior Vice President, Fed. Regulatory Affairs, Verizon (Jan. 26, 2010), 25 F.C.C.R. 937, DA 10-136; Letter from Joel Gurin and Ruth Milkman to Vonya B. McCann, Senior Vice President, Gov't Affairs, Sprint Nextel Corp. (Jan. 26, 2010), 25 F.C.C.R. 941, DA 10-137.

70 In the Matter of Implementation of Section 6002(b) of the Omnibus Budget Reconciliation Act of 1993 Annual Report and Analysis of Competitive Market Conditions With Respect to Mobile Wireless, Including Commercial Mobile Services, Fourteenth Report, FCC 10-81, WT Docket No. 09-66, ๆ 234 (May 20, 2010) available at http:/fjallfoss.fcc.gov/edocs_public/attachmatch/FCC-10-81 Al.pdf.

71 In re Empowering Consumers to Avoid Bill Shock, FCC 10-180, _(rel. October 14, 2010); see also John Horrigan and Ellen Satterwhite, Americans' Perspectives on Early Termination Fees and Bill Shock-Summary of Findings (May 26, 2010), available at 
The present Commission's focus on "affordable" pricing, which it apparently believes is not widely available, is not limited to more direct attempts to control the conduct of firms. In the National Broadband Plan, for example, the agency proposes to "develop rules for one or more spectrum bands requiring licensees to provide a free or very low-cost broadband service tier." 72 This proposal is aimed directly at addressing "the affordability barrier to adoption."73 Plainly, this Commission is committed to lowering prices for services using its regulatory influence. As such, price regulation must be viewed as a genuine threat to broadband firms.

Finally, we have the recent acquisition of Mobile Satellite Service ("MSS") provider SkyTerra by Harbinger Capital Partners, which the Commission snuck out the door on delegated authority to the International Bureau, the Wireless Bureau, and the Office of Engineering and Technology. ${ }^{74}$ Although the Bureau Chiefs raised serious concerns about the merged entity's potential dominance of the MSS market (including a finding that Harbinger had ownership positions in MSS competitor TerreStar, along with a variety of other wireless competitors $)^{75}$, what tipped the Bureau Chiefs' hands was their acceptance of the merged entity's promise to build a " $4 \mathrm{G}$ " terrestrial (as opposed to satellite) wireless network that "will provide coverage in the United States to at least 100 million people by December 31,2012 , at least 145 million people by December 31, 2013, and at least 260 million people by December 31, 2015."

While one can certainly see the appeal of Harbinger's offer, the Bureau Chiefs went one step further by adopting a de facto spectrum cap without the benefit of an opportunity for public notice and comment. ${ }^{77}$ In particular, Har-

http://hraunfoss.fcc.gov/edocs_public/attachmatch/DOC-298414A1.pdf.

72 NATIONAL BROADBAND PLAN, supra note 14, at 173.

73 Id.

74 In re Matter of SkyTerra Communications, Inc. and Harbinger Capital Partners Funds, Applications for Consent to Transfer of Control of SkyTerra Subsidiary, LLC, Memorandum Opinion and Order and Declaratory Ruling, 25 F.C.C.R. 3059, 3085 (hereinafter the Harbinger Order).

${ }_{75}$ Id. 153 . Significantly, and germane to this paper, the Bureau Chiefs expressly recognized that because "companies have changed their plans over the past years, both in response to changing economic times and to changes in Commission rules," it is no wonder why MSS companies' business plans remain, in the Bureau Chiefs' own words, "fluid." Id. II 54.

76 Id. 956.

77 Indeed, contrary to this Administration's promise of "transparency", although the ex partes containing voluntary commitments were made on March 26, 2010, the Commission did not post these ex partes on EDOCs until March 29th-three days after the order was released. See Letter from Henry Goldberg, Attorney, to Marlene Dortch, Sec. of Fed. Commc'ns Comm'n,

(Mar.

26 ,

2010)

(available

at 
binger first promised that if it seeks to make spectrum available "to either of the two largest terrestrial providers of CMRS and broadband services," the merged entity must obtain Commission approval. ${ }^{78}$ Second, the merged entity must live up to the order's proposed build-out schedule. Finally, the merged entity must first obtain Commission approval before traffic to these largest terrestrial providers' accounts for more than twenty five percent (25\%) of SkyTerra's total traffic on its terrestrial network in any Economic Area. ${ }^{79}$ These "voluntary commitments" have no apparent nexus to any specific anticompetitive harm revealed by the Bureau Chiefs' competitive analysis. Rather, this "spectrum cap" regulation is nothing more than an inappropriate backdoor attempt to regulate indirectly by adjudication rather than by industry-wide rulemakings. ${ }^{80}$

\section{Any Notion that Forbearance is "Easy" Ignores Precedent}

A critical component of the "Third Way" to regulate broadband services is the application of forbearance authority to purge Title II regulation of its more heavy-handed elements. Forbearance, however, is not an easy task and is unlikely to be sufficiently applied. Although the Commission may set forth a list of regulations it may seek to forbear on its own motion, ${ }^{81}$ given the complexity of the issue, there will no doubt be multiple items left off this list that will prompt additional petitions for forbearance from broadband service providers. Moreover, the standard for forbearance is quite high, and there is no guarantee of success. Forbearance will certainly be challenged by some parties, with such protests having support from at least one Commissioner. ${ }^{82}$

Under Section 10 of the Communications Act (47 U.S.C. $\S 160(a)(1)-(3))$, the Commission:

[S] hall forbear from applying any regulation or any provision of [the Communica-

http://fjallfoss.fcc.gov/ecfs/document/view?id=7020397552). Thus, it was impossible by administrative fiat to for the public to have an opportunity to comment on Harbinger's "voluntary commitment" of a de facto spectrum cap.

78 Harbinger Order, supra note 74, at $\uparrow 72$.

$79 \quad$ Id. 972.

80 Thomas M. Koutsky and Lawrence J. Spiwak, Separating Politics from Policy in FCC Merger Reviews: A Basic Legal Primer of the "Public Interest" Standard, 18 СомMLAW CONSPECTUS 329, 330 (2010).

81 See e.g., Genachowski Statement, supra note 3, at 5 (describing the Commissioner's proposed Third Way approach to regulation); Schlick Statement, supra note 5, at 3-4.

82 As noted above, Commission Copps made clear that he "would have preferred plain and simple Title II reclassification" and believes the Commission "must avoid another forbearance binge." Copps Statement, supra note 41, at 1. 
tions] Act to a telecommunications carrier or telecommunications service ... in any or some of its or their geographic markets, if the Commission determines that:

(1) enforcement of such regulation or provision is not necessary to ensure that the charges, practices, classifications, or regulations by, for, or in connection with that telecommunications carrier or telecommunications service are just and reasonable and are not unjustly or unreasonably discriminatory;

(2) enforcement of such regulation or provision is not necessary for the protection of consumers; and

(3) forbearance from applying such provision or regulation is consistent with the public interest.

Moreover, in making its public interest determination under subsection (3),

the Commission shall consider whether forbearance from enforcing the provision or regulation will promote competitive market conditions, including the extent to which such forbearance will enhance competition among providers of telecommunications services. If the Commission determines that such forbearance will promote competition among providers of telecommunications services, that determination may be the basis for a Commission finding that forbearance is in the public interest. ${ }^{83}$

Although the Commission must act upon a request for forbearance within one year, ${ }^{84}$ this is not an easy process for the petitioner. Not only does an applicant bear both the "burden of proof" and the "burden of persuasion", ${ }^{85}$ but the Commission specifically rejected the argument that it has "an ongoing burden to justify regulation"; stating that there is "no burden of proof on the Commission "clearly' written into the statute. . . ." By definition, therefore, any reclassification of broadband transport as a "telecommunications service" would immediately subject network operators to a bevy of regulations that the Commission may (or may not), at its discretion, eventually decide to drop.

Furthermore, the Commission proposes simultaneously to regulate and forbear, and it is not clear how the statute can be sensibly interpreted to permit both. For example, to forbear from price regulation, the Commission must conclude that prices are "just and reasonable" and "not unjustly or unreasonably discriminatory." 87 Since its National Broadband Plan concludes $\$ 25$ is the benchmark of "affordable" (i.e., what consumers are willing to pay) ${ }^{88}$ can the

83 Communications Act, 47 U.S.C. § 160(b)

84 Communications Act, 47 U.S.C. \& 160 (c).

85 In re Petition to Establish Procedural Requirements to Govern Proceedings for Forbearance Under Section 10 of the Communications Act of 1934, as Amended, REPORT AND ORDER, 24 F.C.C.R. 9543, 9554, ศा 20,21 (June 26, 2010).

86 Id. $\ 22$ (internal citations omitted).

8747 U.S.C. $\S 160(a)(1)$.

88 John Horrigan, Broadband Adoption and Use in America 5 (OBI WORKING PAPER SERIES No. 1 Feb. 2010), available at http://hraunfoss.fcc.gov/edocs_public/attachmatch/DOC-296442Al.pdf 
agency deregulate prices if they are not $\$ 25$ or less? Moreover, can competition be sufficient to ensure that prices are "just and reasonable," but practices are not? That is, is it sensible for the Commission to forbear from price regulation due to competition, but then apply "practices" regulation (e.g., under Network Neutrality) due to a lack of competition? The potential for conflict in simultaneously regulating and forbearing is apparent, and the Commission has yet to set forth how it plans to avoid such inherent contradictions.

\section{The Commission Cannot Pre-Commit to Leave Forbearance Intact}

It is well established in Administrative Law that an agency is permitted to change course provided that they articulate "a good reason" for the change. ${ }^{89}$ Thus, as Commissioner Clyburn recently conceded, "there is no such thing as 'certainty' in the regulatory context. Beyond constitutional constraints, certainty is just not a reality under any regulatory framework." 90 Commissioner Clyburn argues, therefore, that instead of efforts to promote regulatory certainty, "[m]aybe the more accurate term then is regulatory predictability. That is, industry is searching for a reasonable probability that any one course will continue. Framing it this way at least recognizes the fact that any assumptions on which long-term investments are based have some non-zero chance of being undermined." 91

The distinction between "predictability" and "uncertainty" is a distinction without a difference. As observed by scientist Yuejian Zhu, "[i]ncreases in forecast predictability always correspond to decreases in forecast uncertainty." 92 But whether one calls it "regulatory certainty" or "regulatory predictability," the present case does not concern something as trivial as the FCC's new approach to handle a "wardrobe malfunction" but the capital market's reaction to the FCC's stated intention to radically change course after the private sector has invested (and sunk) hundreds of billions of dollars in reliance of a policy of "light regulatory touch," exogenously enforced by the courts, under the Commission's Title I ancillary jurisdiction.

This is why Chairman Genachowski's and Mr. Schlick's claims that the FCC has never reversed itself ring so hollow. ${ }^{93}$ As evidenced by the Commis-

89 See, e.g., FCC v. Fox Television Stations, 129 S.Ct. 1800, 1811 (2009).

90 Clyburn June 3, 2010 Speech, supra note 38, at 3.

91 Id. at 4.

92 Yuejian Zhu, Ensemble Forecast: A New Approach to Uncertainty and Predictability, 22 ADVANCES IN ATMOSPHERIC SCIENCES 781, 782 (2005).

93 See Schlick Statement, supra note 5, at 9 (explaining how the FCC "has never re- 
sion's apparent willingness to reverse nearly six years of bi-partisan agreement (and findings of fact upheld by the courts) ${ }^{94}$ holding that broadband services should be treated as an interstate service under Title I, no unbiased observer would be likely to expect that regulators will not reverse course when circumstances are propitious.

Ironically, the reclassification decision itself reverses an earlier decision to classify broadband access as a Title I service. ${ }^{95}$ Broadband service providers were signaled by the Commission, and affirmed by the courts, that they could make long-term investment decisions based on Title I classification. ${ }^{96}$ The Commission now proposes to radically modify the regulatory scheme. This reversal of the agency's previous regulatory posture demonstrates that a sitting administration cannot credibly bind the actions of future administrations. Indeed, current Commissioner and former Acting-Chairman Copps has explicitly noted his preference for "plain and simple Title II reclassification through a declaratory ruling." 97

\section{Despite its Protestations, the Commission Continues to Send Signals that Unbundling is Back on the Table}

Another example of the FCC's light touch for advanced services was the deliberate decision to allow local exchange companies to "invest their way out of regulation" by exempting "new wires" (i.e., fiber) from requirements to unbundle legacy copper networks. ${ }^{98}$ Although Chairman Genachowski stated that his "Third Way" would "not change established policy . . to unbundling",

versed a forbearance determination made under section 10 , nor one made for wireless under the similar criteria of section 332 (c) (1); Genachowski Statement, supra note 3, at 5.

94 See Letter From Members of Congress, to Julius Genachowski, Chairman of Fed. Commc'ns Comm'n (May 24, 2010) (signed by 74 House Democrats); Letter from Members of U.S. Senate, to Julius Genachowski, Chairman, Fed Commc'ns Comm'n (May 24, 2010) (signed by 37 Senate Republicans).

95 See Nat'l Cable \& Telecomms. Ass'n v. Brand X Internet Servs., 545 U.S. 967, 968969 (2005).

96 Id. at 1001-1002.

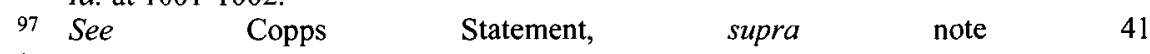

at 1. See Tom Tauke, A New Principle for a New Era: The Courage to Let Broadband Grow, Address at NARUC/NECA National Broadband Summit (Apr. 28, 2003) (referencing his 2001 Old Wires, Old Rules/New Wires, New Rules speech in Aspen, CO). See also William H. Dutton, Sharon E. Gillett, Lee W. McKnight \& Malcolm Peltu, Bridging broadband Internet divides: reconfiguring access to enhance communicative power, 19 JOURNAL OF INFO. TECH. 28-38 (March 2004).

99 Genachowski Statement, supra note 3, at 5. 
the FCC nonetheless keeps making repeated overtures that unbundling, or the requirement that incumbent local phone companies lease portions of their networks at regulated prices to facilitate retail competition, may be back on the table.

By way of background, unbundling was never designed to create a static, incumbent-centric perpetual resale market. ${ }^{100}$ Rather, in the same vein as the FCC's WATTs Resale and Competitive Carrier paradigms of the late seventies and 1980s, the purpose of unbundling was to stimulate and consolidate new, non-incumbent demand to justify the construction of alternative networks. ${ }^{101}$ Yet, as the telecom bubble of the 1990's bore out, the economics of the business dictated that the number of wireline networks would be few. ${ }^{102}$ Given that the majority of Americans now have access to both a cable and telecommunications provider, ${ }^{103}$ both of which offer assorted packages of voice, data and video (not to mention the addition of imperfect substitution from multiple wireless providers), a strong argument can be made that the original objectives of the 1996 Act have been met. ${ }^{104}$

Notwithstanding, there are several provisions in Chapter 4 of the National Broadband Plan that refer to "wholesale competition regulations." Although the Plan did not call for a return to unbundling outright, the Plan did recommend that the "FCC should comprehensively review its wholesale competition

100 See T. Randolph Beard, George S. Ford \& Lawrence J. Spiwak, Why ADCo? Why Now? An Economic Exploration into the Future Industry Structure for the "Last Mile" in Local Telecommunications Markets, 54 FED. COM. L. J. 421, 422-425 (2002) (describing how unbundling creates a non-incumbent demand for competitive infrastructure).

101 See Final Acts of the World Administrative Telegraph and Telephone Conference Melbourne, 1988 (Wattc-99): International Telecommunication Regulations, INT'L TELECOMM. UNION 3-8 (1989), available at http:/itu.int/dms_pub/itus/oth/02/01/s02010000214002PDFE.pdf; see Dean Burch, Common Carrier Communications by Wire and Radio: A Retrospective, 37 FED. COMM. L.J. 85, 88-91 (1985); see Jerry A. Hausman \& J. Gregory Sidak, Did Mandatory Unbundling Achieve Its Purpose? Empirical Evidence From Five Countries, 1 J. CoMP. L. \& EcoN. 173, 182-183 (2005).

102 See Beard, supra note 100, at 422-425 (describing how prevailing market conditions limited the number of wire line networks).

103 Hausman, supra note 101 , at 181 ; see In re A National Broadband Plan for Our Future, Comments of the United States Telecom Ass 'n), GN Docket No. 09-51, at 3-4 (June 8, 2009),

http://www.ustelecom.org/uploadedfiles/issues/filings/20090608_comments.USTelecom.Br oadband.NOI.GN.09.51.pdf (describing how "over 90\%" of Ämerican households have access to "wireline or a cable broadband service" while nearly "four-fifths of U.S. households have access to both.").

104 See Jim Robbins, The 1996 Telecommunications Act, 58 FED. COMM. L.J. 559, 560563,568 (2006) (describing the effects of recent legislation that facilitated the rise of different voice, data and multimedia packages from broadband providers). 
regulations to develop a coherent and effective framework and take expedited action based on that framework to ensure widespread availability of inputs for broadband services provided to small businesses, mobile providers, and enterprise customers." 105 According to the Commission, this inquiry specifically includes "competitive access to local fiber facilities." 106 Moreover, there also appears to be some Congressional support for the Commission's suggestion, ${ }^{107}$ and a Commission-sanctioned study explicitly called for the use of unbundling to spur broadband adoption. ${ }^{108}$

In the same vein, the Commission recently denied a petition by Qwest Communications for forbearance of certain unbundling obligations in the Phoenix area. ${ }^{109}$ Yet, what is significant about this Order is not the fact that the Commission denied the petition, but that the Commission rejected the legal standard it used in all of its prior forbearance precedent in favor of a far stricter standard that may, in practice, be impossible to overcome. ${ }^{110}$ Specifically, instead of focusing on whether or not the market was workably competitive (i.e., performance), the Commission reverted back to a "counting heads" analysis of the number of firms in the market to determine whether the incumbent pos-

105 National Broadband Plan, supra note 14, at 36.

106 See $i d$. at 48 (citing to Pleading Cycle Established For Comments On Petition For Expedited Rulemaking Regarding Section 271 Unbundling Obligations, Public Notice, 24 F.C.C.R. 14,514 (Dec. 14, 2009); Comment Sought On Maine Public Utilities Commission Petition For Declaratory Ruling Regarding Section 271 Access to Dark Fiber Facilities And Line Sharing, Public Notice, 25 F.C.C.R. 372 (Jan. 15, 2010).

107 Transcript of Oversight of the Federal Communications Commission: The National Broadband Plan: Hearing Before the H. Subcomm. On Commc'ns, Tech., and the Internet of the H. Comm. On Energy and Commerce, 111 th Cong. 178-179 (Mar. 25, 2010), available at http://energycommerce.house.ogv/press_111/20100325/transcript.03.25.210.cti.pdf.

108 THE BERKMAN CENTER FOR INTERNET \& SOCIETY AT HARVARD UNIVERSITY, NEXT GENERATION CONNECTIVITY: A REIVEW OF BROADBAND INTERNET TRANSITIONS AND POLICY FROM AROUND THE WORLD (Feb. 2010), available at http://cyber.law.harvard.edu/newsroom/broadband_review_final); Yochai Benkler, Ending the Internet's Trench Warfare, Editorial, N.Y. TIMES, March 21, 2010, at WK12. For a forceful dismantling of the Berkman Study, see GEORGE S. FORD, PHOENIX CTR. FOR THE Advanced Legal \& Econ. Pub. Pol'y. Studies, Whoops! Berkman Study Shows “Open ACCESS" REDUCES BROADBAND CONSUMPTION (NOV. 12, 2009), available at http://www.phoenix-center.org/perspectives/Perspective09-05Final.pdf.

109 In re Matter of Petition of Qwest Corporation for Forbearance Pursuant to 47 U.S.C. $\S 160(\mathrm{c})$ in the Phoenix, Arizona Metropolitan Statistical Area, Memorandum Opinion and Order, FCC 10-113, 25 F.C.C.R. 8622, 8623 (June 15, 2010).

${ }^{110}$ George S. Ford and Lawrence J. Spiwak, Phoenix Center Perspective No. 1008, The Impossible Dream: Forbearance After the Phoenix Order (Dec. 16, 2010) available at http:/www.phoenix-center.org/perspectives/Perspective10-08Final.pdf (showing that the FCC's new "market power" analysis requires price to equal marginal cost). 
the number of firms in the market to determine whether the incumbent possessed market power. ${ }^{111}$ Given that 1) the economics of the business dictate that industry structure will always be highly concentrated and characterized by few firms; and 2) just as importantly, such concentration, in the face of high fixed and sunk costs, does not necessarily mean a market may be performing poorly (in fact, such structure may indicate the presence of intense price competition). ${ }^{112}$ The Commission's new approach to forbearance virtually guarantees that unbundling obligations will remain on the books, regardless of whether the costs of those regulations outweigh the public interest benefits. ${ }^{113}$

For better or worse, the United States' ten year experiment with forcing local exchange carriers to unbundle their legacy local copper loops came to a screeching halt with the D.C. Circuit's decision in USTA II. ${ }^{114}$ There, the Court found that, despite repeated attempts by the Commission to define adequately the "necessary" and "impair" standard of Section 251, the Commission simply could not come up with a standard with sufficient granularity to write enforceable rules. ${ }^{115}$ If the FCC could not write legally sustainable rules to unbundle the legacy copper network in a monopoly environment, it strains credulity to think that the FCC could draft legally sustainable unbundling rules for fiber and coaxial cable, and possibly even mobile broadband networks, in the current workably competitive broadband environment.

Yet, as noted above, so long as the Commission continues to make overtures to revisit unbundling, the Commission's credibility in this regard is very much in doubt. From an incumbent investor standpoint, there is a real risk that the government will again seek to reduce profitability; and from a CLEC investor

111 Id. q4 41-45.

112 See generally, George. S. Ford, T. M. Koutsky \& Lawrence J. Spiwak, Competition After Unbundling: Entry, Industry Structure and Convergence, 59 FED. COMM. L.J. 331, 332-3334, 337-348 (2007).

113 See In re Petition of Qwest Corporation, supra note 109, ๆ 90:

We find that de novo entry is equally unlikely. As discussed above, in the Triennial Review Order, the Commission found that competitive carriers face extensive economic barriers to the construction of last-mile facilities. Congress enacted and the Commission implemented the UNE framework in an attempt to lower barriers to entry and to create a viable platform for entry into the local market. We see nothing in the record to indicate that the passage of time has lowered these barriers for competitive LECs that do not already have an extensive local network used to provide other serId. vices to enterprise locations today. (Internal Citations Omitted)

114 Rebecca Arbogast, FCC's Broadband Quartet: A State-Federal Fugue or Feud?, 2 J. on TeleCOMM. \& High TeCH. L 245, 252 (2003); United States Telecom Ass'n v. FCC (USTA II), 359 F.3d 554, 561 (D.C. Cir. 2004).

115 USTA II, 359 F.3d at $563,571-573$. 
standpoint, as the entire unbundling experience of the telecom bubble sends a clear message that what the government can give one moment the government can take away the next, why would any rational investor risk one dime of precious capital in another CLEC only to be burned twice?

\section{RECLASSIFICATION AND INVESTMENT: THEORY AND EVIDENCE}

A core message of the National Broadband Plan is that government must do what it can to encourage private investment in broadband infrastructure. ${ }^{116}$ Investment effects have proven to be a key component in all legislative and regulatory debates regarding the communications industries. ${ }^{117}$ Reclassification is no exception, and the Statements reflect concern for the effects of reclassification for capital expenditures on broadband infrastructure. Chairman Genachowski, for example, contends that the basic goal of broadband policy is "to encourage private investment and the building of a communications infrastructure," 118 but he expresses concern that "[h]eavy-handed prescriptive regulation can chill investment and innovation." 119 Nonetheless, the Chairman proposes reclassification of broadband services, and also proposes that the agency "[s]imultaneously renounce . . . application of the many sections of the Communications Act that are unnecessary and inappropriate for broadband access service; and [p] ut in place up-front forbearance and meaningful boundaries to guard against regulatory overreach." ${ }^{20}$ In effect, the Chairman proposes to expose the industry to "heavy-handed" regulation but then have the agency restrain itself in applying much of it.

Restraint is, obviously, a choice and a decision that no single person at a

116 See National Broadband Plan, supra note 14, at 9, (explaining how the plan "addresses the troubling gaps and unrealized opportunities in broadband in America by recommending ways federal, state and local governments can unleash private investment ....").

117 See e.g., Press Release, Fed. Commc'ns Comm'n, Jen Howard, Spokesperson, FCC Statement on Comcast v. FCC Decision (Apr. 6, 2010) (on file with author); In re Inquiry Concerning High-Speed Access to the Internet Over Cable and Other Facilities, Internet Over Cable Declaratory Ruling, Appropriate Regulatory Treatment for Broadband Access to the Internet Over Cable Facilities, Declaratory Ruling and Notice of Proposed Rulemaking, 17 F.C.C.R. 4798, 4840, 973 (Mar. 14, 2002).

118 Genachowski Statement, supra note 3, at 1-4; Schlick Statement, supra note 5, at 3; In re Framework for Broadband Internet Service, Reply Comments of the Telecommunications Industry Association, GN Docket No. 10-127, 1, 22-23 (Aug. 12, 2010) [hereinafter TIA Comments].

119 Genachowski Statement, supra note 3, at 1-4.

120 Id. at 5. 
regulatory agency has the authority to make. Whether or not self-directed "forbearance" and self-imposed "boundaries" will be sufficient, or could be credibly implemented and enforced, is unknown. Therefore, it is fair to say that reclassification will expose with a positive and increased probability, the Internet to "heavy-handed" regulations that "chill investment." 121 In other words, it seems fair to say that the existence of strong authority under Title II will not diminish, but will in fact increase the chances that ultimately, the broadband firms face significant price regulation.

Thus, all Internet firms, and particularly broadband service providers, would plausibly and reasonably incorporate a higher probability of prescriptive regulation into their investment decisions upon reclassification. By the Chairman's own logic, this higher probability will "chill investment." ${ }^{122}$ In contrast, the existing approach of the Commission to "not regulate the Internet" and "[refraining] from regulation when possible," has "promot[ed] investment in the Internet and broadband technologies . . ." 123

In the next section, we present a theoretical model of investment decisions. In this model, firms face a probability of "strong" regulation (i.e., heavyhanded, prescriptive regulation) in future periods. Investment decisions are made based on expectations regarding the strength of future regulation. This model matches closely the present scenario of the potential introduction of a Title II framework for the regulation of broadband Internet services. It is clear that the introduction of Title II regulation will affect the potential investor in several complex ways. However, from the provider's point-of-view, as Chairman Genachowski observed, the relevant issue is the provider's ability to earn "a healthy return on investment", which "is a necessary and desirable incentive to risk-taking and deployment of capital." "124 The nature, extent, and severity of any regulation materially affects prospective returns, and the Chairman has already recognized that Title II regulation reduces returns and chills investment incentives.

In addition, discussion of potential reclassification of broadband services has at times emphasized that the implementation of Title II would go some distance in reducing uncertainty inherent in the current environment. Chairman Genachowski believes staying the course "creates serious uncertainty about the Commission's ability, under this approach, to perform the basic oversight

121 Id. at 2-5. See TIA Comments, supra note 118.

122 See Genachowski Statement, supra note 3, at 2 (describing the chilling effect of heavy-handed prescriptive regulation on investment and innovation).

123 Schlick Statement, supra note 5, at 1-2.

124 Genachowski Statement, supra note 3, at 3. 
functions, and pursue the basic broadband-related policies, that have been long and widely thought essential and appropriate," 125 and that reclassification "eliminat[es] as much of the current uncertainty as possible." ${ }^{26}$ Likewise, Mr. Schlick claims, "stick[ing] with the information service classification . . is a recipe for prolonged uncertainty. . . The extended uncertainty would deprive investors ... of needed clarity about the rules of the road." 127

These linkages between uncertainty and investment tend to confuse the ideas of uncertainty, and profitability. Investment is deterred by greater uncertainty when the uncertainty affects the spread of the returns on investments. ${ }^{128}$ Reducing regulatory uncertainty by making heavy-handed regulation more likely reduces average investment returns. Therefore, in this instance, a reduction in uncertainty is accompanied by a reduction in expected returns. We will illustrate the effects of regulatory uncertainty on investment using theoretical analysis first, and then discuss the linkage between the theory and the empirical tests presented above.

\section{A. Theoretical Model}

In section II.A above, we considered a simple game between a firm contemplating an investment decision, and a regulator. This model, though very abstract, illustrated a basic inefficiency inherent in many regulatory situations: the regulator is generally unable to bind its future actions in a credible manner, leading to diminished incentives for firms to make welfare-improving investments. However, one may legitimately object that the circumstances described in this model are too simple: the future behavior of regulators cannot be deduced in advance, given the uncertainties of economic circumstances, political events, technological changes, and so on.

The basic point made earlier continues to apply, and in a more nuanced way, when these inherent uncertainties are explicitly included in the analysis. Our

125 Id. at 3-4.

$126 \mathrm{Id}$. at 5.

127 Schlick Statement, supra note 5, at 2-3.

128 See Warren G. Lavey, Making and Keeping Regulatory Promises, 55 FED. CoMm. L.J. 1, 7-8 (2003) (citing Joint Application of AT\&T Corp. and Telec-communications, Inc. for Transfer of Control to AT\&T Licenses and Authorizations Held by TCI and Its Affiliates or Subsidiaries, AT\&T's and TCI's Joint Reply to Comments and Joint Opposition to Petitions to Deny or to Impose Conditions, CS Docket No. 98-178, app. B, at 20-21 (filed Nov. 13, 1998)). See TIA Comments, supra note 118, at 20 (commenting that "unsurprisingly, the investment-deterrent effect of regulation increases as more Title II obligations are applied, substantially reducing the "net present value' of a proposed investment."). 
that the diminished investment phenomenon can be intuitively related to the practical problem facing the FCC; whether or not to regulate broadband services using the Title II framework. Our conceptualization of this issue is straightforward. We will view Title II classification as resulting in an increase in the probability of strong regulatory intervention, and we will show that, given this effect, Title II will reduce investment.

In the interest of the simplest presentation of the core issue, we consider a two-period model with only two agents, a broadband firm B and a sociallydirected regulator $F$. While one could presumably always argue against any expansion of regulatory authority by resorting to the claim that the regulators would act inefficiently or in opposition to the public interest, such claims are not the focus of our analysis. We will assume throughout that the regulator acts to maximize social benefits given current circumstances.

The potential investor B must decide on the level of sunk investment, denoted $k$, to make in furtherance of its business plans. The difficulty, as is often the case, is that the potential investor is both uncertain about the nature of future regulation, and recognizes that it will find itself in a weak position vis-àvis the regulator due to its inability to recover previous investment costs through exit or asset sales. The firm that makes an irreversible investment faces a risk that the regulator, acting to maximize total surplus in some future period, will act so as to preclude full recovery of the costs after the investments are sunk. ${ }^{129}$ Surplus maximization in the future does not imply surplus maximization today, and this theoretical analysis demonstrates this idea, as did the game theoretical analysis above.

Uncertainty (or lack of predictability) over the regulator's policy can mean that the regulator's future behavior is unknown ex ante. From the firm's standpoint, though, uncertainty is relevant only insofar as it concerns the returns available; the "nuts and bolts" of the regulatory mechanism are of secondary importance compared to the firm's ability to satisfy creditors and obtain investment capital. ${ }^{130}$ Thus, let $\theta$ denote the probability the firm assigns to facing strong regulation, and let $1-\theta$ denote the corresponding probability that regu-

129 See Elizabeth Olmsted Teisburg, Capital Investment Strategies under Uncertain Regulation, 24 RAND J. ECON. 591, 593-594 (1993) (providing an overview of the problems firms may face with large capital investments that are irreversible, and the subsequent uncertainty from future government regulation).

130 See A. Miguel Márquez García \& M. Jesús Hernández Ortiz, Firms Facing Uncertainty: The Cooperation Option, in MANAGING UnCERTANTY: THEORY \& PRACTICE 435 (Constantin Zopandis \& Panos M. Pardalos eds., Kluwer Academic 1998) (illustrating several different attitudes in how firms may approach future uncertainty). 
lation is relaxed. Although we will assign very specific meanings to "strong" and "relaxed" regulation in what follows, our argument does not depend on these specific interpretations, as will be seen below.

The order of actions is as follows. First, both the regulator and firm observe $\theta$. Second, the firm makes an irreversible investment $k$, with cost $r k$, where $r, k>0$. This investment choice determines the firm's costs of providing service, given by $T C=c(k) Q+r k$, where $Q$ is the quantity of service produced per period, $c(k)$ is the unit costs of service, and $r$ is the cost per unit of idiosyncratic capital investment $k$. We assume, in accord with standard economics, that $c$ is decreasing in $k$, but at a decreasing rate, so that $c^{\prime}<0, c^{\prime \prime}>0$. (So $c$ is a convex, decreasing function of $k$ ).

Third, the nature of the regulatory environment is revealed: with probability $\theta$ the firm will be subjected to "strict" regulation, which we take to mean the regulator $F$ will engage in social welfare maximizing price regulation of the firm. In contrast, with probability $1-\theta$, the resulting regulation will be "relaxed", meaning that prices will not be regulated, and the firm may act relatively freely to set prices and so on. (Although these two outcomes are very different, we will show that they may be relaxed below.)

In order to solve the firm's investment problem, we first consider the firm's behavior under relaxed regulatory oversight. In this case, we may presume that the firm selects prices, given unit cost $c(k)$, to solve the problem:

$$
\pi_{R}=[(p-c) Q(p)]
$$

where $Q(p)$ is the market quantity demanded at price $p$ and $\pi_{R}$ represents the firm's profits (ignoring the capital investment cost $r k$ ). Thus, in this case the firm sets prices to maximize its returns. Application of the envelope theorem establishes that $\pi_{R}$ is decreasing in unit cost $c: \partial \pi_{R} / \partial c=-Q<0$.

In contrast, suppose that the strong regulatory regime is imposed, as occurs with probability theta $(\theta)$. In this case, the regulator $F$ will set prices directly to maximize the sum of producer and consumer surplus. This results in a price of $c(k)$ per unit. Notice here that, given the circumstances in which it finds itself, the regulator $\mathrm{F}$ is behaving precisely in the social interest should this eventuality come to pass.

Having determined the possible future circumstances in which it might find itself, $\mathrm{B}$ faces the following investment maximization problem:

$$
\max \pi(k, \theta)=(1-\theta) \pi_{R}(c(k))-r k
$$

where the maximization is performed over $k$ for the given value of $\theta$. Here, we introduce a standard technical assumption: the "profit function" given by the 
introduce a standard technical assumption: the "profit function" given by the solution to this problem is well-defined, so that the underlying cost and demand conditions are consistent with this program being concave. In this case, the unique maximal solution is found by solving the condition $\partial \pi\left(k^{*}, \theta\right) / \partial k=0$. This relationship specifies the optimal investment choice $k^{*}$ as a function of the probability of strong ex post optimal regulation $\theta$. In other words, the firm's choice of investment depends on the probabilities with which different sorts of future regulation will occur.

We turn next to the critical issue: how will a change in $\theta$, the probability of "strong" regulation, affect investment $k^{*}$ ? This question has an immediate answer in this simple behavioral model: ${ }^{131}$

$$
\frac{\partial k^{*}}{\partial \theta}=\frac{\partial^{2} \pi / \partial k \partial \theta}{-\partial^{2} \pi / \partial k^{2}}
$$

In words, an increase in the probability of the strong (ex post social welfare maximizing) regulation will reduce the initial investment of the firm, and thereby reduce ultimate service levels, and increase unit costs.

The mechanism described above is not novel: this effect has long been a concern in regulatory settings where substantial sunk investments are made and regulators are unable to credibly pre-commit to their future behavior. ${ }^{132}$ However, the presentation given here illustrates, in a realistic way, the likely effects of the service reclassification dynamic associated with the Title II regu-

131 The denominator is positive by concavity (for maximization), so the numerator signs the expression. The numerator can be written as $\left(\partial \pi_{2} / \partial \mathrm{c}\right)(\partial c / \partial k)<0$, where $\partial \pi^{2} / \partial \mathrm{c}<0$ and $\partial c / \partial k<0$. Thus, the numerator is negative and the sign of the expression is negative.

132 Teisberg, supra note 128, at 591-604. See also Jean Jacques Laffont and Jean Tirole, Should Governments Commit?, 36 EuROPEAN ECON. REV. 345-353 (1992); Paul de Bijl \& Martin Peitz, Regulation and ENTRY INTO TElECOMMUNiCATIONS MARKETS 246 (2002):

"if the regulator cannot pre-commit to such principles, operators face regulatory uncer tainty when taking investment decisions. In particular, entrants may start more cautiously to see which regulation applies in the segments with competition to update their beliefs about regulation that will prevail in other market segments. The consequence of such staggered entry is a delay in investment. As a result, the market as a whole matures more slowly, that is, entrants choose a smaller coverage, or roll out a less elaborate network, than without regulatory uncertainty. This increases the need for heavy regulation for two reasons. Firstly, larger parts of the market remain a monopoly; and secondly, regulatory uncertainty favors entry modes in which sunk costs are low. This implies that overall regulatory uncertainty creates a bias in favor of resale-based entry and against facilitiesld. based entry." 
lation of broadband. Regulation is a complex, multifaceted undertaking, and it is not easy to accurately describe it in simple terms. Yet, the following facts are indubitable.

First, in contrast to the arguments of Chairman Genachowski, Austin Schlick, and Commissioner Clyburn, uncertainty about the nature of future regulation is not, per se, an issue. Rather, when people complain about such uncertainty, they usually really mean that investment returns are unknown because the nature or severity of regulation is unknown. In this model, the parameter $\theta$ represents this uncertainty. Notice, though, that any change in $\theta$ that moves $\theta$ closer to the midpoint $(\theta=1 / 2)$ is an increase in uncertainty, while moves of $\theta$ closer to the endpoints 0 and 1 are "reductions" in uncertainty. But, any increase in $\theta$, whether constituting an increase or a reduction in uncertainty, will reduce investment and raise unit costs of service. Thus, the claim that Title II will reduce uncertainty, even if true, is not relevant to investment levels, welfare, or prices.

Second, as discussed above in Section II, FCC actions suggest that Title II will amount to an increased probability of strong, price regulation of broadband services. Both common sense and empirical evidence support this interpretation. Thus, in this sense, the effect of Title II reclassification will be given as an increase in $\theta$ in this model. This finding is not due to any claim that the FCC will behave contrary to the public interest in the future; on the contrary, we assume they will behave as perfect ex post welfare maximizers. But the FCC, as a government body with political administration, cannot, as a matter of policy, constrain future lawful acts of the FCC through lawful acts today. ${ }^{133}$ This constraint, though, has at least one unfortunate consequence, and the investment reduction affects described there are an example of this.

Finally, it is not the case that our findings depend, in any strict sense, on the exact regulatory actions we described as strong or relaxed. For example, the finding persists if the strong regulatory regime allows for some mark-up in pricing, so prices exceed marginal cost $(c)$. Similarly, the relaxed regime need not be completely unregulated. What is essential for our finding is that the strict regime reduces profits attendant on the investment in a substantial way compared to the relaxed regulation outcome.

133 See Genachowski Statement, supra note 3 at 5; Schlick Statement, supra note 5, at 8 (noting that "neither approach would, could, or should absolutely prevent the Commission from adjusting its future policies in light of changed circumstances.") 


\section{B. From Theory to Empirics}

Chairman Genachowski's view that "[h]eavy-handed prescriptive regulation can chill investment" 134 is supported by economic theory. Now, the question is whether there is empirical evidence to further confirm the relationship between broadband investment and reclassification. To that end, we turn to financial theory to develop an empiric model.

As explained by Tobin, "the rate of investment-the speed at which investors wish to increase the capital stock-should be related, if to anything to $q$, the value of capital relative to its replacement cost." 135 This " $q$ " is a financial statistic computed as the ratio of market value to replacement value. The $q$ theory of investment holds that as $q$ rises, investment rises. The theory is widely used in the economics and finance literature. Chirinko, in his thorough review of the statistical analysis of investment, explains that the $q$-theory of investment "has been the most popular explicit model in empirical investment studies." 136

The $q$-theory is useful here because market capitalization - that is, the value of common stock-is a significant element of the numerator of the $q$-ratio. ${ }^{137}$ Changes in stock returns imply changes in the $q$-ratio, and by the $q$-theory, changes in the rate of investment. ${ }^{138}$ Therefore, from this evidence, it is possible to shed light on additional investment in broadband infrastructure resulting from reclassification.

In the Statements, both Chairman Genachowski and Mr. Schlick allege that the "Third Way" is not a highly regulatory approach to broadband rules, and as such should not attenuate private investment in the sector. Chairman Genachowski claims that reclassification "would not change the range of obligations that broadband access service providers faced pre-Comcast," and Mr. Schlick

\footnotetext{
134 Genachowski Statement, supra note 3 at 2.

135 James Tobin, A General Equilibrium Approach to Monetary Theory, in EsSAYS IN ECONOMICS: MACROECONOMICS 330 (Vol. 1, 1981).

136 Robert S. Chirinko, Business Fixed Investment Spending: Modeling Strategies, Empirical Results, and Policy Implications, 31 JourNAL of ECON. LiT. 1875, 1889 (1993).

137 See, e.g., Steven N. Kaplan and Luigi Zingales, Do Investment-Cash Flow Sensitivities Provide Useful Measures of Financing Constraints?, 112 QUARTERLY JOURNAL OF ECON. 169 (1997); Timothy Erickson and Toni M. Whited, Measurement Error and the Relationship between Investment and " $q$ ", 108 JOURNAL OF POLITICAL ECONOMY 1027 (2000).

138 Eric B. Lindenberg \& Stephen A. Ross, Tobin's " $q$ " Ration and Industrial Organization, 54 JOURNAL OF BUSINESS 1-32 (1981). "Financial price data provide a viewing window into the firm through the market's valuation of the securities issued by the firm and the changes in these values over time." Id. at 1 .
} 
asserts that the "Third Way" would "preserve the status quo, not change it."139 If reclassification merely preserves the status quo and leaves unchanged regulatory obligations, then the financial markets should view reclassification as an innocuous regulatory event. But if the markets respond negatively, then investors can be assumed to have concluded that the Commission lacks the necessary credibility for "light touch" regulation.

In this Section, we conduct a brief empirical examination of the financial markets' reaction to the FCC's proposal. We utilize the widely-accepted event study methodology for this purpose. ${ }^{140}$ Our empirical analysis is straightforward. To discern the financial market response to reclassification, we gathered data on stock price returns for broadband providers in the multichannel video distribution business (i.e., cable operators). We also collected such data on video distributors with no significant presence in the broadband access business (i.e., satellite providers). If the financial markets find the Commission's "light touch" approach to be credible, then stock returns should be largely unaffected by the reclassification proposal. This logic suggests that we may examine stock prices at the instant of the relevant announcement, and assess the FCC's credibility (as far as the capital markets are concerned) by testing for significant effects in those price series.

\section{Econometric Model}

Following Karafiath, let $t=1,2, \ldots, T$ denote the pre-event time period and $t=T+1, \ldots, T+N$ denote the event period. ${ }^{141}$ The regression model is:

$$
R_{j t}=\alpha_{j}+\beta_{j} R_{m t}+\sum_{T+1}^{T+N} \gamma_{j n} D_{n t}+\varepsilon_{t},
$$

where $R_{j t}$ denotes the daily return (i.e., log different) on security $j$ at time $t, R m t$ is the return on the market index at time $t$, and $D_{n t}$ is a dummy variable that is

139 Schlick Statement, supra note 5, at 8.

140 For reviews of the event study, see, e.g., Sanjai Bhagat, Event Studies and the Law; Part I: Technique and Corporate Litigation, 4 AMER. L. AND ECON. REV. 141 (2002); William H. Wells, A Beginner's Guide to Event Studies, 22 Journal OF INSURANCE REgulATION 61 (2004).

141 See, e.g., Imre Karafiath, Using Dummy Variables in the Event Methodology, 23 THE FINANCIAL REV. 351 (1988). See also John J. Glascock \& Imre Karafiath, Statistical inference in Event Studies Using Multiple Regression, in ALTERNATIVE IDEAS IN REAL ESTATE INVESTMENT: RESEARCH ISSUES IN REAL ESTATE SERVICE 177-189 (A. Schwartz ed. 2000). 
equal to one at time $\mathrm{T}$ and zero otherwise. The coefficient $\beta_{j}$ is the financial Beta for security $j ; \gamma_{j n}$ is the excess return on security $j$ at time $t$. The event study focuses on the statistical significance of the $\gamma$ values, or the sum thereof. Since Khotari and Warner pointed out the advantages of "short term" event studies, the pre-event period consists of daily returns for a year prior to the event $(T=250)$ and we set a five-day event period (so there are five "pulse" dummy variables, for a total sample of 255 observations). ${ }^{142}$ The Statements were released on May 6, 2010, so the event dummies include five dummy variables for the dates May 4, 5, 6, 7, and 8 .

Equation (4) is estimated by ordinary least squares for four cable companies: Comcast (CMCSA); Time Warner Cable (TWC); Cablevision Systems (CVC); and Mediacom Communications (MCCC). To ensure that the effects for the cable companies are related to the reclassification and not some video industry shock of another sort, we also estimate the equation for satellite multichannel video distributors DirecTV (DTV) and Dish Network (DISH). Neither satellite company is a meaningful provider of broadband Internet services, so we use these two firms as a "control group" for video-industry shocks coincident with the event window.

\section{Results}

Results are summarized in Table 1 . The $\mathrm{R}^{2}$ values are typical for stock return regressions. Provided in the table are the coefficients and t-statistics for each of the pulse dummy variables. The null hypothesis-that reclassification maintains the status quo (the stock price effect is zero)-is evaluated by a test that the sum of the $\gamma_{j}$ coefficients equals zero. The test statistic for this latter test is distributed $\chi^{2}$ with one degree of freedom (a log likelihood test of the coefficient restriction). ${ }^{143}$ The critical values from the $\chi^{2}$ distribution are 3.84 at the $5 \%$ level and 2.71 at the $10 \%$ level.

142 S.P. Khotari \& Jerold B. Warner, Econometrics of Event Studies, in HANDBOoK of CORPORATE FINANCE: VOL. 1, (B. Espen Eckbo, ed. 2007), available at http://ssrn.com/abstract=608601). Daily returns cover the pre-event period March 4, 2009 through April 29, 2010 (250 daily returns). Returns data provided by finance.yahoo.com.

143 Damodar N. Gujarati, BASIC ECONOMETRICs 280-81 (1995). 


\begin{tabular}{|c|c|c|c|c|c|c|c|}
\hline \multicolumn{8}{|c|}{ Table 1. Regressions Results } \\
\hline & CMCSA & TWC & $\mathrm{CVC}$ & $\mathrm{MCCC}$ & DTV & DISH & CATV \\
\hline$\alpha_{0}$ & $\begin{array}{l}0.000 \\
(-0.34)\end{array}$ & $\begin{array}{l}0.001 \\
(1.12)\end{array}$ & $\begin{array}{l}0.001 \\
(0.51)\end{array}$ & $\begin{array}{l}-0.001 \\
(-0.76)\end{array}$ & $\begin{array}{l}0.001 \\
(0.99)\end{array}$ & $\begin{array}{l}0.000 \\
(0.31)\end{array}$ & $\begin{array}{l}0.000 \\
(025)\end{array}$ \\
\hline$\beta_{1}$ & $\begin{array}{l}1.049 \\
(13.36)^{\mathrm{a}}\end{array}$ & $\begin{array}{l}1.099 \\
(12.50)^{\mathrm{a}}\end{array}$ & $\begin{array}{l}1.212 \\
(12.5)^{\mathrm{a}}\end{array}$ & $\begin{array}{l}1.848 \\
(11.77)^{\mathrm{a}}\end{array}$ & $\begin{array}{l}0.736 \\
(10.39)^{\mathrm{a}}\end{array}$ & $\begin{array}{l}1.233 \\
(9.86)^{\mathrm{a}}\end{array}$ & $\ldots$ \\
\hline$\gamma_{1}$ & $\begin{array}{l}0.001 \\
(0.05)\end{array}$ & $\begin{array}{l}-0.013 \\
(-0.81)\end{array}$ & $\begin{array}{l}-0.007 \\
(-0.42)\end{array}$ & $\begin{array}{l}0.012 \\
(0.42)\end{array}$ & $\begin{array}{l}-0.006 \\
(-0.47)\end{array}$ & $\begin{array}{l}-0.008 \\
(-0.34)\end{array}$ & $\begin{array}{l}0.004 \\
(0.43)\end{array}$ \\
\hline$\gamma_{2}$ & $\begin{array}{l}0.000 \\
(-0.02)\end{array}$ & $\begin{array}{l}0.002 \\
(0.14)\end{array}$ & $\begin{array}{l}0.008 \\
(0.45)\end{array}$ & $\begin{array}{l}0.007 \\
(0.25)\end{array}$ & $\begin{array}{l}-0.012 \\
(-0.88)\end{array}$ & $\begin{array}{l}-0.004 \\
(-0.17)\end{array}$ & $\begin{array}{l}-0.002 \\
(-0.17)\end{array}$ \\
\hline$\gamma_{3}$ & $\begin{array}{l}-0.030 \\
(-2.00)^{\mathrm{a}}\end{array}$ & $\begin{array}{l}-0.048 \\
(-2.92)^{\mathrm{a}}\end{array}$ & $\begin{array}{l}-0.034 \\
(-1.88)^{b}\end{array}$ & $\begin{array}{l}-0.047 \\
(-1.59)\end{array}$ & $\begin{array}{l}0.015 \\
(1.14)\end{array}$ & $\begin{array}{l}0.011 \\
(0.48)\end{array}$ & $\begin{array}{l}-0.040 \\
(-3.8)^{\mathrm{a}}\end{array}$ \\
\hline$\gamma_{4}$ & $\begin{array}{l}0.008 \\
(0.57)\end{array}$ & $\begin{array}{l}-0.007 \\
(-0.42)\end{array}$ & $\begin{array}{l}0.007 \\
(0.40)\end{array}$ & $\begin{array}{l}-0.085 \\
(-2.9)^{\mathrm{a}}\end{array}$ & $\begin{array}{l}0.037 \\
(2.85)^{\mathrm{a}}\end{array}$ & $\begin{array}{l}0.023 \\
(1.00)\end{array}$ & $\begin{array}{l}-0.019 \\
(1.84)^{\mathrm{b}}\end{array}$ \\
\hline$\gamma_{5}$ & $\begin{array}{l}-0.063 \\
(-4.23)^{\mathrm{a}}\end{array}$ & $\begin{array}{l}-0.044 \\
(-2.67)^{a}\end{array}$ & $\begin{array}{l}-0.077 \\
(-4.2)^{\mathrm{a}}\end{array}$ & $\begin{array}{l}-0.003 \\
(-0.11)\end{array}$ & $\begin{array}{l}0.010 \\
(0.75)\end{array}$ & $\begin{array}{l}-0.027 \\
(-1.13)\end{array}$ & $\begin{array}{l}-0.046 \\
(-4.4)^{\mathrm{a}}\end{array}$ \\
\hline $\begin{array}{l}\sum \gamma_{j}=0 \\
\left(\chi^{2}\right)\end{array}$ & $\begin{array}{l}-0.083 \\
(6.31)^{\mathrm{a}}\end{array}$ & $\begin{array}{l}-0.108 \\
(6.38)^{\mathrm{a}}\end{array}$ & $\begin{array}{l}-0.103 \\
(8.55)^{\mathrm{a}}\end{array}$ & $\begin{array}{l}-0.115 \\
(2.99)^{b}\end{array}$ & $\begin{array}{l}0.046 \\
(2.30)\end{array}$ & $\begin{array}{l}-0.002 \\
(0.001)\end{array}$ & $\begin{array}{l}-0.102 \\
(19.5)^{b}\end{array}$ \\
\hline $\mathrm{R}^{2}$ & 0.44 & 0.42 & 0.41 & 0.41 & 0.33 & 0.28 & $\ldots$ \\
\hline
\end{tabular}

Note: Statistically-significant at the $5 \%$ level $\left({ }^{a}\right)$ and $10 \%$ level $\left({ }^{b}\right)$.

From Table 1 we see large negative returns for all the cable company stocks during the event period. Over the event window, the negative abnormal returns for the cable operators are about $10 \%$ on average, and all are statistically significant at the $10 \%$ level or better. ${ }^{144}$ The cumulative abnormal return for Comcast is about $-8 \%$, but it is $-11.5 \%$ for Mediacom. Time Warner Cable and Cablevision have negative returns of about $10.5 \%$ over the event window. Constraining the coefficients on the pulse dummies to be equal across the cable

144 The general findings are unaffected if the equations are estimated as a system (using Seemingly Unrelated Regression) or if bootstrapping is used for hypothesis testing. See, e.g., George S. Ford and Audrey D. Kline, Event Studies for Merger Analysis: An Evaluation of the Effects of Non-Normality on Hypothesis Testing, in ANTITRUST POLICY Issues, Ch. 8 (2006); John Jackson, Audrey Kline \& Sarah Skinner, The Impact of Non-Normality and Misspecification on Merger Event Studies, 7 INT'L J. OF THE ECONOMICS OF BUSINESS 247, 248-264 (2006). 
operators (labeled "CATV" in the final column of Table 1), the estimated cumulative abnormal return is $-10.2 \%$, which is statistically different from zero at better than the $1 \%$ level $\left(\chi^{2}=19.47\right)$.

The results for DirecTV and Dish Network indicate that the cable operators' negative returns do not reflect a shock of the video programming market. The coefficients on the pulse dummies for these companies are not statistically different from zero, save one exception (where the coefficient is positive). Nor are the cumulative abnormal returns for the firms statistically different from zero at standard levels. DirecTV had about a $5 \%$ positive return over the window, although this result is only very marginally significant (at the $15 \%$ level). Dish Network's abnormal returns are essentially zero both quantitatively and statistically. This evidence suggests that the large negative abnormal returns for the broadband providers were a response to reclassification and not a multichannel video industry shock. In other words, the markets looked at the FCC's Statements and sent the stock prices of the relevant firms significantly downward. This decline suggests that the capital markets accept neither the FCC's promises nor their characterization of the proposed change in regulation. Since investment is determined by the capital markets, this is strong evidence that the reclassification scheme will undermine the allocation of new resources to broadband infrastructure, even if the FCC ultimately keeps its word.

\section{Other Evidence on Credibility and Investment Effects}

As our theoretical discussion has demonstrated, the investment effects of reclassification depend on beliefs about the future actions of the Commission. In the previous section, we considered formal evidence from the financial markets regarding investor beliefs about the credibility of light touch regulation. This evidence indicated that the markets expect heavy-handed regulation in the future in response to reclassification and discounted broadband provider stocks accordingly. As a consequence, investment in broadband networks is expected to decline (ceteris paribus). The theoretical and empirical analysis above is also supported by more anecdotal evidence in the form of commentary by industry and financial analysts.

First, industry analysts plainly expect reclassification to lead to more heavyhanded regulation. For example, Greg Miller of Collins Stewart, LLC observes:

Reclassification could act as a Trojan horse for greater regulation: Although the plan sounds fine on paper, in that the FCC intends to allow all carriers to continue practic- 
ing reasonable network management, the plan would also provide the FCC nearly unfettered authority to regulate this segment of the economy, should it decide it is necessary to alter its planned forbearance practice on all other aspects of broadband communications. ${ }^{145}$

And, while the Chairman and Mr. Schlick claim price regulation and unbundling are not on the table, few believe this to be true. For example, Craig Moffett, a New York-based analyst with Sanford C. Bernstein \& Co., said that "cable operators" and "Verizon" could be forced to "share . . . network with competitors." 146 Bernstein Research states frankly, "[t]he potential for price regulation speaks to longer term expected growth rates." 147 Clearly, the investment community now perceives that "light-touch" regulation lacks credibility.

The implications for capital expenditures in the industry are also understood. For example, Bank of America/Merrill Lynch states:

Based on our analysis the potential for lower investment are likely and the ramifications will be felt not just in telecom and cable, but potentially in the vendor sector as well. We believe the only leverage carriers have beyond the Courts in this debate are jobs and investment and both could be threatened by this move. ${ }^{148}$

Likewise, Craig Moffett predicts reclassification will have "profoundly negative impact on investment." 149 And, Standard and Poor's analyst Tuna Amobi noted that a "'third-way' framework . . . creates potential long-term negative investment (and competitive) implications for major cable broadband providers." ${ }^{150}$ These views on regulation and investment are entirely consistent with our theoretical and empirical analysis. The fact that the Commission cannot credibly commit to "light touch" regulation with Title II authority, and the consequent negative effects on investment, are widely accepted.

145 Greg Miller, FCC Moving Closer to Some Title II Regulations? Collins Stewart, LLC (May 7, 2010).

146 Todd Shields, FCC Begins Reclaiming Authority Over Internet Access Providers, BLOOMBERG BUSINESSWEEK (May 6, 2010, 4:50 PM EDT), http://www.businessweek.com/news/2010-05-06/fcc-reclaims-powers-over-internet-accesscompanies-update3-.html.

147 Bernstein Research, U.S. Cable: Pulling the Plug . . Regulatory Uncertainty Clouds Terminal Growth Rates; Downgrading Sector to Neutral (May 10, 2010).

148 Internet Regulation Back on the Front Burner, BANK OF AMERICA/MERRILL LYNCH (May 5, 2010).

149 Shields, supra note 146.

150 William Spain, FCC Chief Broaches New Approach on 'Net Neutrality', MARKETWATCH (May 6, 2010, 4:39 P.M EDT), http://www.marketwatch.com/story/cable-shareshit-by-fcc-move-on-net-neutrality-2010-05-06). 


\section{DEFINING THE BOUNDARIES OF TITLE I ANCILLARY AUTHORITY}

\section{A. Why the FCC Lost in Comcast}

Despite some popular misconceptions, ${ }^{151}$ broadband was never totally deregulated. Rather, broadband was lightly regulated under the FCC's ancillary Title I jurisdiction, as opposed to heavily regulated under Title II. ${ }^{152}$ Although perhaps not the cleanest of legal arguments, the concept and enforceability of the FCC's ancillary jurisdiction is very real and established by the courts. ${ }^{153}$ After all, as the Supreme Court made quite clear in Brand $X$, the "Commission remains free to impose special regulatory duties on facilities based [Internet Service Providers] under its Title I ancillary jurisdiction." 154 The question, therefore, is why did the FCC lose in Comcast?

Although there is a wide swath of theories as to why the FCC lost in Com-

151 For discussion on the Title II regulation see Sam Gustin, The FCC's 'Third Way' on Net Neutrality Reignites Broadband Fight, DaILYFINANCE.COM (May 7, 2010, 9:00 AM), http://www.dailyfinance.com/story/media/fcc-third-way-on-net-neutrality-reignitesbroadband-fight/19467729/. See Ryan Womach, American Broadband Market Works, Economists Say, BroadBandBREaKFAST.com (June 15, 2009, 1:21 PM), http://broadbandbreakfast.com/2009/06/american-broadband-market-works-economistssay/. For discussion on misconceptions regard broadband deregulation, see Lawrence Spiwak, The FCC's disingenuous 'third way' on broadband, CNET News (May 19, 2010, 12:32 PM PDT), http://news.cnet.com/8301-1035_3-20005416-94.html.

152 See, e.g., Petition for Declaratory Ruling that pulver.com's Free World Dialup is Neither Telecommunications Nor a Telecommunications Service, WC Docket No. 03-45, Memorandum Opinion, 19 F.C.C.R. 3307 (2004); Inquiry Concerning High-Speed Access to the Internet Over Cable and Other Facilities; Internet Over Cable Declaratory Ruling; Appropriate Regulatory Treatment for Broadband Access to the Internet Over Cable Facilities, GN Docket No. 00-185, CS Docket No. 02-52, Declaratory Ruling and Notice of Proposed Rulemaking, 17 F.C.C.R. 4798, 4832, I 59 (2002) (Cable Modem Reclassification Order), aff'd, NCTA v. Brand X, 545 U.S. 967 (2005); Framework for Broadband Access to the Internet over Wireline Facilities; Universal Service Obligations of Broadband Providers, CC Docket Nos. 02-33, 01-337, 95-20, 98-10, WC Docket Nos. 04-242, 05-271, Report and Order and Notice of Proposed Rulemaking, 20 F.C.C.R. 14853, 14864, 14909-11, ๆ 15, ๆ 103-04 (2005) (Wireline Broadband Reclassification Order), aff'd sub nom. Time Warner Telecom, Inc. v. FCC, 507 F.3d 205 (3rd Cir. 2007); Wireless Broadband Classification Order, supra note 47; United Power Line Council's Petition for Declaratory Ruling Regarding the Classification of Broadband over Power Line Internet Access Service as an Information Service, WC Docket No. 06-10, Memorandum Opinion and Order, 21 F.C.C.R. 13281, 13288, I 11 (2006) (BPL Reclassification Order).

153 See, e.g., United States v. Southwestern Cable Co., 392 U.S. 157, 178 (1968); United States v. Midwest Video Corp., 406 F.3d 689, 691 (1972) [hereinafter Midwest Video I].

154 Brand X, 545 U.S. at 998. 
cast, perhaps the most straightforward explanation is that the Commission simply wrote a bad order. According to the court, in order to prove ancillary authority, the Commission must satisfy a two-part test distilled in American Library Association v. FCC. ${ }^{155}$ First, the Commission must show that the regulated subject under consideration falls under the Commission's general jurisdictional grant under Title I of the Communications Act; and second, that the "regulations are reasonably ancillary to the Commission's effective performance of its statutorily mandated responsibilities."156 As agreed in the Comcast case, broadband networks fell under the Commission's broad Title I authority because the Internet service qualifies as "interstate and foreign communications by wire"; the primary issue before the court was whether the Commission had made a compelling argument that it satisfied the second prong of the American Library test, which is to tie the proposed regulation to the Commission's express statutory objectives under Title II, III, or VI of the Act. ${ }^{157}$

The Commission never did. Rather, the Commission attempted to hook its ancillary authority to (among other sections) Section 230(b), which provides that "[i]t is the policy of the United States . . . to promote the continued development of the Internet and other interactive computer services" and "to encourage the development of technologies which maximize user control over what information is received by individuals, families, and schools who use the Internet." 158 Similarly, the Commission cited to the language of Section 1, which provides that the purpose of the Communications Act is to "regulat[e] interstate and foreign commerce in communication by wire and radio so as to make available, so far as possible, to all the people of the United States . . . a rapid, efficient, Nation-wide, and world-wide wire and radio communication service . . . at reasonable charges . ..."159 The court rejected both arguments, finding that "policy statements alone cannot provide the basis for the Commission's exercise of ancillary authority." 160 According to the court, this rule derives from the "axiomatic" principle that "administrative agencies may [act] only pursuant to authority delegated to them by Congress." Policy statements are just that-statements of policy. They are not delegations of regulatory authority. ${ }^{161}$

155 American Library Ass'n. v. FCC,406 F.3d 689, 700 (D.C. Cir. 2005).

$156 I d$. at 691-92.

157 Comcast, 600 F.3d at 646-47.

158 Id. at 651; Communications Decency Act, 47 U.S.C. $\S 230$ (b) (2006).

159 Comcast, 600 F.3d at 646-647; 47 U.S.C. $\$ 152$ (a).

160 See Comcast, 600 F.3d at 651-652,654 (referencing 47 U.S.C. $\S 151$ (2006)

161 Id. at 654. By the same logic, the court also rejected the FCC's citation to Section 706's statement that the Commission "shall encourage" the deployment of advanced tele- 
The next area of concern was statutory provisions where the court found that the Commission could have at least made plausible arguments, but for both "substantive and procedural" reasons failed to do so. ${ }^{162}$ For example, the Commission cited to Section 256, which directs the Commission to "establish procedures for . . oversight of coordinated network planning ... for the effective and efficient interconnection of public telecommunications networks." ${ }^{163}$ However, the court chided the agency for neglecting to mention the same statute goes on to read that that "[n]othing in this section shall be construed as expanding ... any authority that the Commission" otherwise has under law . ..." which, in the court's view, was precisely what the Commission was trying to do in the Comcast case. ${ }^{164}$

The court next tackled the Commission's use of Section 257. Under Section 257 , the Commission is supposed to both complete a proceeding (long-since accomplished) "identifying and eliminating, by regulations pursuant to its authority under this chapter (other than this section), market entry barriers for entrepreneurs and other small businesses in the provision and ownership of telecommunications services and information services" and then issue a follow-up report every three years on remaining barriers. ${ }^{165}$ The court's response was quite interesting. According to the court,

We readily accept that certain assertions of Commission authority could be "reasonably ancillary" to the Commission's statutory responsibility to issue a report to Congress. For example, the Commission might impose disclosure requirements on regulated entities in order to gather data needed for such a report. But the Commission's attempt to dictate the operation of an otherwise unregulated service based on nothing more than its obligation to issue a report defies any plausible notion of "ancillariness." 166

The court also rejected the Commission's attempt to link its ancillary jurisdiction to its limited authority to regulate cable rates under Section 623. According to the court, the Commission's Section 623 argument fails "because, unlike its Title II authority over common carrier rates, its section 623 authority is sharply limited." 167 The court explained that not only does Section 623 prohibit "the Commission from regulating rates for "video programming offered on a . .

communications services. According to the court, "the Commission is seeking to use its ancillary authority to pursue a stand-alone policy objective, rather than to support its exercise of a specifically delegated power." Id. at 658-659.

162 Id. at 644.

163 See Id. at 659 (referencing 47 U.S.C. $\$ 256(\mathrm{~b})(1)$ ).

164 Comcast, 600 F.3d at 659.

16547 U.S.C. $\$ 257$ (a) (2006).

166 Comcast, 600 F.3d at 659-660 (citing to Motion Picture Ass'n of Am. v. FCC, 309

F.3d 796, 801-802 (D.C. Cir. 2002)(Emphasis added).

167 Id. at 661 . 
. per program basis,' i.e., video-on-demand service", but its "current authority is limited to setting standards for and overseeing local regulation of rates for 'basic tier' service on certain cable systems." 168 However, the court found that the FCC did not even assert ancillary authority based on this narrow grant of regulatory power; instead, the court chided the Commission for arguing that "Section 1 gives the Commission ancillary authority to ensure reasonable rates for all communication services, including those, like video-on-demand, over which it has no express regulatory authority."169

That said, the court sent clear signals on how the Commission could have written a better order. For example, the court appeared to be sympathetic to the Commission's argument in the Comcast Order, which stated that "by blocking certain traffic on Comcast's Internet service, the company had effectively shifted the burden of that traffic to other service providers, some of which were operating their Internet access services on a common carrier basis subject to Title II." 170 Moreover, "by marginally increasing the variable costs of those providers, the Commission maintained, Comcast's blocking of peer-to-peer transmissions affected common carrier rates" under Section 201. ${ }^{171}$ This approach adheres to the basic template of ancillary authority, where the regulation is tied to obligations found in Title II. However, because the Commission failed to make this argument on appeal, the court held that it was precluded from considering it. ${ }^{172}$

Conversely, the Commission argued that "Voice over Internet Protocol (VoIP) services .... affect the prices and practices of traditional telephony common carriers subject to Section 201 regulation." ${ }^{173}$ The Commission noted that "some VoIP services were disrupted by Comcast's network management practices." 174 However, the court rejected this argument on appeal because it was not originally advanced in the Comcast Order. ${ }^{175}$ Again, a straightforward application of ancillary authority that ties the regulations to a direct statutory mandate.

The court found also that "the same problem undercuts the Commission's effort to link its regulation of Comcast's network management practices to its

$168 \mathrm{Id}$.

$169 I d$.

170 See id. at 660 (referencing the Comcast Order, 13 F.C.C.R. 13,037-38 at 17 ).

171 Id.

$172 \mathrm{Id}$. at 660.

173 Comcast, 600 F.3d at 660.

174 Id. at 660-661.

$175 \mathrm{Id}$. 
Title III authority over broadcasting." 176 On appeal, the Commission contended that 'Internet video 'has the potential to affect the broadcast industry' by influencing 'local origination of programming, diversity of viewpoints, and the desirability of providing service in certain markets." 177 Yet, as before, the court noted that "the Commission cited no source for this argument in the [Comcast] Order", and therefore the court found that the Commission's argument was precluded on appeal. ${ }^{178}$

\section{B. Writing a Better Order}

The Comcast court makes it abundantly clear that if the FCC wants to create a legally enforceable Title I regime to protect consumers, it is certainly within its powers to do so. The FCC simply needs to make a sound argument about what it wants to do and tie such actions to a clearly ancillary authority under the Act. ${ }^{179}$ Below, we consider two primary areas of the debate: transparency and blocking of traffic.

\section{Transparency}

There is wide consensus that transparency will make a giant contribution towards ensuring what many refer to (vaguely) as an "Open Internet."180 In fact, transparency - and not a bright-line non-discrimination rule-is precisely how the European Union handled this very issue. ${ }^{181}$ Fortunately, much of the intellectual "heavy lifting" to develop an ancillary jurisdiction paradigm for transparency has already been done by the Commission itself. ${ }^{182}$

176 Id.

177 Comcast, 600 F.3d at 660 .

178 Id. at 660.

179 Id. at 646

180 See Julius Genachowski, Chairman, Fed. Commc'ns Comm'n, Preserving a Free and Open Internet: A Platform for Innovation, Opportunity, and Prosperity, Prepared Remarks at The Brookings Institute (Sept. 21, 2009); see also In re Preserving the Open Internet Broadband Industry Practices, Reply Comments of the Open Internet Coalition, GN Docket No. 09-191, WC Docket No. 07-52 (Apr. 26, 2010).

181 See, e.g., Lawrence J. Spiwak, Bright Lines, Big Problems, Forbes.COM (Jan. 12, 2010, 2:00 PM EST), http://www.forbes.com/2010/01/12/networl-neutrality-europeanunion-fcc-opinions-contributors-lawrence-j-spiwak.html). See also Council Directive 2009/136, 2009 O.J. (L 337) If 32 (EC), available at http://eurlex.europa.eu/LexUriServ/LexUriServ.do?uri=OJ:L:2009:337:001 1:0036:EN:PDF).

182 See Wireline Broadband Reclassification Order, supra note 152, ๆ 108. 
As the Commission has already recognized, and courts have affirmed, ${ }^{183}$ "the predicates for ancillary jurisdiction are likely satisfied for any consumer protection, network reliability, or national security obligation that we may subsequently decide to impose on wireline broadband Internet access service providers." ${ }^{84}$ While this statement was made under the Martin Commission, the Genachowski Commission continues to share this view. ${ }^{185}$ Indeed, in 2009's "Truth-in-Billing" Notice of Proposed Rulemaking, the agency appeared to set forth a sound rationale on how it could extend its Title I ancillary authority to broadband service providers. ${ }^{186}$

In particular, the Commission set forth two reasons why "both of the predicates for ancillary jurisdiction are likely to be satisfied for consumer protection obligations that it may decide to impose on non-Title II services such as broadband Internet access and subscription video services." 187 First, the Commission noted that it has "subject matter jurisdiction over the providers of these services." 188 In the Commission's view, these services "clearly constitute either 'wire communication' as defined in Section 3(52), when they take the form of signals transmitted by wire or cable, or 'radio communication' as defined in Section 3(33), and when they take the form of signals transmitted by radio."189 Moreover, the Commission argued that "Section 2(a) of the Act gives the Commission subject matter jurisdiction over 'all interstate and foreign communications by wire or radio ... and . . . all persons engaged within the United States in such communication." 190 Second, the Commission argued that

consumer protection regulation of at least some of these services would be similar to the regulation that [it] found in the Wireline Broadband Internet Access Services Order to be 'reasonably ancillary' to the Commission's responsibility to implement Section 222 (customer privacy), 255 (disability access), and 258 (slamming and truth-inbilling), among other provisions of the Act. ${ }^{191}$

While one never knows how this exact argument will be viewed by a review-

183 Id. ๆ 340.

184 Id. $\mathbb{1} 109$.

185 See In re Consumer Information and Disclosure, Truth-in-Billing and Billing Format, IP-Enabled Services, Notice of Inquiry, CG Docket No. 09-158, CC Docket No. 98-170, WC Docket No. 04-3624 F.C.C.R. 11380, 11399, || 61 (Aug. 27, 2009).

186 Id.

187 Id. 962.

188 Id. 63

$189 \mathrm{Id}$.

190 Id. $\mid$ 63; see 47 U.S.C. $\$ 152(\mathrm{a})$.

191 See In re Consumer Information and Disclosure, Truth-in-Billing and Billing Format, IP-Enabled Services, Notice of Inquiry, CG Docket No. 09-158, CC Docket No. 98-170, WC Docket No. 04-3624 F.C.C.R. 11380, 11399, शף 62 -63 (Aug. 27, 2009). 
ing court, the Commission at least appears to address all of the legal pitfalls highlighted by the Comcast court.

\section{Blocking of Traffic}

At bottom, perhaps the central fear behind the "Open Internet" debate is the concern that a BSP will somehow block or degrade a competitor's product in favor of its own traffic. The Commission attempted to address this issue in the Open Internet NPRM by using a tortured interpretation of the interconnection provisions contained in Section 251 as a mechanism to impose price regulation. ${ }^{192}$ As demonstrated above, however, not only does the Commission's proposed pricing rule violate the existing jurisprudence behind Section 202, but it also violates the Commission's own precedent when originally implementing Section 251 in 1996.

More importantly, previous research has clearly demonstrated that the Commission's pricing regulation has it "backwards" in that the proposed rules would actually encourage-not deter-exclusionary behavior. ${ }^{193}$ By foreclosing the use of prices to acquire surplus, the firms are incentivized to use alternative and less desirable means such as sabotage, foreclosure, or vertical merger. ${ }^{194}$ Regulation induces such actions, not simply profit maximization. ${ }^{195}$ Given these numerous analytical flaws, accepting the FCC's Open Internet NPRM as currently adopted is simply bad public policy.

Rather than inappropriately using Section 251 as a pricing statute, ${ }^{196}$ the Commission should correctly use the interconnection and access provisions contained in Section $251^{197}$ as an analytical anchor for ancillary authority. This approach would prevent firms from engaging in some sort of strategic anticompetitive conduct by blocking or degrading lawful IP traffic. In other words,

192 In re Preserving the Open Internet Broadband Industry Practices, Notice of Proposed Rulemaking, FCC 90-93, CG Docket No. 09-191, WC Docket No. 07-52 (Oct. 22, 2009).

193 George Ford and Michael Stern, Sabotaging Content Competition: Do Proposed Net Neutrality Regulations Promote Exclusion?, 16 PhOENIX CENTER PERSPECTIVE No. 10-02 (2010), available at http:/www.phoenix-center.org/perspectives/Perspective10-02Final.pdf.

194 Id. at n. 28.

195 Id. at 5.

196 FORD \& SPIWAK, supra note 47.

197 Under Section 251(a)(1), each "telecommunications carrier has the duty - to interconnect directly or indirectly with the facilities and equipment of other telecommunications carriers." Moreover, under Section 251(c)(2), incumbent local exchange carriers must provide such interconnection "at any technically feasible point"; be "at least equal in quality to that provided by the local exchange carrier to itself or to . . . any other party"; and on "rates, terms and conditions that are just, reasonable and nondiscriminatory ...." 
"practices" regulation, not price regulation.

This approach is not a revolutionary idea. For example, University of Pennsylvania Professor Kevin Werbach argues that the FCC could define two new subset categories of information service providers subject to its ancillary jurisdiction. ${ }^{198}$ Professor Werbach's first subset is those information services "so identical to telecommunications services as to make the distinction purely an invitation for arbitrage." 199 By way of example, Professor Werbach points to the Commission's rejection of AT\&T's petition for declaratory ruling that using "VoIP in the middle" of its backbone warranted regulatory reclassification. ${ }^{200}$ Werbach's second subset would be "broadband access platforms"-i.e., those "hybrid services" that "integrate telecommunications and information services in order to provide end users with access to the Internet." ${ }^{201}$ Under such a definition, argues Professor Werbach, a clear case of ancillarity can be made because

broadband-Internet services and content threaten FCC statutory obligations in two ways: (1) unregulated services can mimic and compete with regulated telecommunications services, and (2) simultaneously, those regulated services can either escape from regulation or harm competitions higher up [the production chain]. ${ }^{202}$

Thus, concludes Werbach, this "narrow approach would avoid the need to impose the full panoply of common-carrier obligations or cable-TV rules on broadband-access providers. "203

Moreover, there is precedent for using Section 251 to make sure IP traffic is

198 Kevin D. Werbach, Off the Hook, 95 CoRNELl L. Rev. 535, 571, 576-81 (2010). We also note that Professor Werbach attempted to tie ancillary jurisdiction to Section 256. However, as noted supra, the Comcast court rejected that argument out of hand, so we need not address it here.

199 Id. at 577.

200 Id. See also In re Petition for Declaratory Ruling that AT\&T's Phone-to-Phone IP Telephony Services Are Exempt from Access Charges, Order, 19 F.C.C.R. 7457 ๆ 12-13 (Apr. 14, 2004).

201 Werbach, supra note 198 , at 578.

202 Id. Under the same logic, an ancillary authority argument could be extended to broadband service (or even transport) directly. Prior court decisions make it relatively clear that ancillary authority can be legitimized in any case where the service or practice of interest has demand or cost interdependencies with a Title II, Title III, or Title VI service. See, e.g., United States v. Southwestern Cable Co. and Midwest Video I supra note 153. Clearly, the increased adoption of broadband services has had significant impacts on the purchase of more traditional voice and video services, and the apparent demand and cost effects of such interdependencies lead directly to a sound argument for ancillary authority.

203 Werbach, supra note 198 at 578 (emphasis added). See also Schlick Statement, supra note 5, at 2-3 (" $[\mathrm{T}]$ he FCC would be on safe legal ground only to the extent its actions regarding emerging broadband services were intended to affect traditional services like telephone and television."). 
terminated. For example, the FCC's Wireline Competition Bureau took a similar approach in 2007 when two rural exchange carriers, both backed by their respective local Public Utilities Commissions, refused to terminate third-party VoIP traffic. ${ }^{204}$ RLECs argue they had no obligation to participate in interconnection agreements with competitive local exchange providers (CLECs) in instances where the CLECs operated wholesale services on behalf of VoIP providers. ${ }^{205}$ In the particular case of the South Carolina dispute, the South Carolina Commission held that the CLEC was not entitled to seek interconnection with the rural incumbent LEC. The South Carolina Commission determined that the CLEC's wholesale service did not fall within the meaning of a "telecommunications service" under the Act. ${ }^{206}$ In the case of the Nebraska dispute, the Nebraska Commission found that the CLEC was not a "telecommunications carrier." There, the Nebraska Commission determined that the relationship between the CLEC and VoIP provider is an "individually negotiated and tailored, private business agreement" that is an untarrifed offering and, therefore, does not fit under the purview of Section $251 .{ }^{207}$ Significantly, the Bureau disagreed with both. ${ }^{208}$ According to the Bureau, the "statutory classification of a third party provider's VoIP service as an information service or a telecommunications service is irrelevant to the issue of whether a wholesale provider of telecommunications may seek interconnection under Section 251(a)." 209 Stated another way, Section 251 commands that all BSPs must terminate and transport all IP traffic, regardless of the source.

Not surprisingly, the current Commission agrees. As the Commission noted in the National Broadband Plan, the Commission "should clarify interconnection rights and obligations and encourage the shift to IP-to-IP interconnection where efficient." 210 Why? Because in the Commission's view, "[f]or competition to thrive, the principle of interconnection - in which customers of one service provider can communicate with customers of another-needs to be maintained." 211 Thus, according to the Commission:

204 In re Time Warner Cable Request for Declaratory Ruing that Competitive Local Exchange Carriers May Obtain Interconnection Under Section 251 of the Communications Act of 1934, as Amended, to Provide Wholesale Telecommunications Services to VolP Providers, Memorandum and Order, 22 F.C.C.R. 3513, 1f 8-16 (March 1, 2007).

205 Id. 73.

206 Id. ๆ 5.

207 Id. 16.

208 Id. $7 \uparrow$ 2-3 (2010).

209 Id. $\ 15$.

210 NATIONAL BROADBAND PLAN, supra note 14, at 49.

211 Id. 
To prevent the spread of this anticompetitive interpretation of the Act and eliminate a barrier to broadband deployment, the FCC should clarify rights and obligations regarding interconnection to remove any regulatory uncertainty. In particular, the FCC should confirm that all telecommunications carriers, including rural carriers, have a duty to interconnect their networks. The FCC should also determine what actions it could take to encourage transitions to IP-to-IP interconnection where that is the most efficient approach. ${ }^{212}$

Given these parameters, developing a legally sustainable access paradigm to protect the "Open Internet" should not be that difficult. The Commission could set up some sort of "rocket docket" to adjudicate access claims. The Commission used such a procedural mechanism quite effectively to enforce the original implementation of Section 251 , and there is no reason why such a mechanism could not be reconstituted. ${ }^{213}$ Second, the Commission could focus on a casespecific inquiry as to whether or not the BSP engaged in some sort of strategic anticompetitive conduct, rather than attempt to regulate the reasonableness of the BSP's day-to-day network management practices. In such cases, we expect there would be some showing of measurable harm. ${ }^{214}$

212 Id.

213 The Commission introduced an Accelerated Docket for formal complaints to effectuate a "prompt resolution of all complaints in order to "reduce impediments to robust competition in all telecommunications markets." 'In re Implementation of The Telecommunications Act of 1996, Amendment of Rules Governing Procedures to Be Followed When Formal Complaints are Filed Against Common Carriers, Second Report \& Order, 13 F.C.C.R. 17,018, 191 1-5, 16-21 (July 9, 1998).

214 In conflict with the common view, profit maximizing broadband providers have too little incentive-relative to the social welfare maximizing level-to remedy congestion problems. Consequently, any action aimed to reduce congestion should be presumed lawful and the burden of proof should rest on those contesting the congestion-reducing activity. See George S. Ford, Thomas M. Koutsky \& Lawrence J. Spiwak, The Welfare Impacts of Broadband Network Management: Can Broadband Service Providers be Trusted?, 6, 8-9, 11-12, 14, 15-17, 19 (2008), available at http://www.phoenixcenter.org/pcpp/PCPP32Final.pdf. See also Gregory L. Rosston \& Michael D. Topper, An Antitrust Analysis of the Case for Wireless Network Neutrality 17, (Stanford Inst. For Econ. Policy Research Discussion Paper No. 08-040, 2009), available at http://www.stanford.edu/group/siepr/cgi-

bin/siepr/?q=system/files/shared/pubs/papers/pdf/08-040.pdf; Robert W. Hahn, Robert E. Litan \& Hal J. Singer, The Economics of Wireless Net Neutrality, 45-47 (AEI-BRooKINGS JOINT CENTER for Regulatory Studies, Working Paper No RP07-10, 2007), available at http://www.naviganteconomics.com/docs/Hahn,Litan,Singer_Economics_of_Wireless_Net Neutrality.pdf; Philip J. Weiser, Toward a Next Generation Regulatory Strategy, 35 LoY. $\vec{U}$. CHI L.J. 41, 81-84 (2003). 


\section{CONCLUSION}

In light of the D.C. Circuit's recent ruling in Comcast v. FCC, ${ }^{215}$ Federal Communications Commission Chairman Julius Genachowski announced that he would seek to reclassify broadband transport as a "telecommunications service" under Title II of the Communications Act. ${ }^{216}$ While providing greater regulatory certainty, this certainty is beneficial solely to the Commission. As the Commission itself concedes, reclassification, increases the regulator's ability to impose ill-suited regulations on broadband. ${ }^{217}$ In fact, Chairman Genachowski recognizes that reclassification "can chill investment and innovation" by reducing "investors confidence." ${ }^{218}$ In an effort to temper the negative effects on investment from such expanded regulation, the Chairman proposed a "Third Way," in which reclassification occurs but the agency "[puts] in place up-front forbearance and meaningful boundaries to guard against regulatory overreach." 219 Put simply, the Chairman is seeking the unhindered authority to impose heavy-handed regulation, but promises not to do so.

This "Third Way" approach to Title II regulation boils down to credibility: can the Commission be trusted to self-impose regulatory moderation? The evidence does not support the Chairman's claim of a "light touch." First, reclassification itself is a reversal of broadband policies in place for nearly a decade. Second, the agency is considering or has recently implemented expanded regulation in many sectors of the communications industry, including the prices of broadband transport and pricing and practices in the wireless sector. Third, while the Commission may have convinced itself that it has such discipline, it recognizes that it cannot pre-commit to long-term moderation. Market participants also recognize and responded to the lack of pre-commitment. Empirical evidence indicates that the investment community does not regard as credible the Chairman's "light touch" promises. Based on a theoretical model of investment and the empirical evidence, a reduction in investment in broadband infrastructure is expected following reclassification.

Finally, we show that the Comcast decision is not a threat to ancillary authority for broadband; the Commission merely has to make better arguments. Indeed, opening the door to heavy-handed regulation that will reduce investment and harm consumer welfare based upon a fear of protracted litigation is

215 Comcast, 600 F.3d at 642.

216 Genachowski Statement, supra note 3, at 5.

217 Id

$218 \mathrm{Id}$.

$219 \mathrm{Id}$. 
no way to make public policy. Although the Chairman's "Third Way" may provide the Commission with a perceived blanket of legal comfort, that legal certainty comes at the expense of financial uncertainty. The Comcast court makes clear that Title I continues to provide sound legal footing to protect consumers from harm-at least until Congress decides to update and amend existing Communications law with a cleaner framework. 